\title{
The gender gap in early career wage growth: the role of children, job mobility and occupational mobility
}

\section{Abdulaziz Abrar Reshid}


The Institute for Evaluation of Labour Market and Education Policy (IFAU) is a research institute under the Swedish Ministry of Employment, situated in Uppsala. IFAU's objective is to promote, support and carry out scientific evaluations. The assignment includes: the effects of labour market and educational policies, studies of the functioning of the labour market and the labour market effects of social insurance policies. IFAU shall also disseminate its results so that they become accessible to different interested parties in Sweden and abroad.

Papers published in the Working Paper Series should, according to the IFAU policy, have been discussed at seminars held at IFAU and at least one other academic forum, and have been read by one external and one internal referee. They need not, however, have undergone the standard scrutiny for publication in a scientific journal. The purpose of the Working Paper Series is to provide a factual basis for public policy and the public policy discussion.

More information about IFAU and the institute's publications can be found on the website www.ifau.se

ISSN 1651-1166 


\title{
The gender gap in early career wage growth: the role of children, job mobility and occupational mobility ${ }^{a}$
}

\author{
by \\ Abdulaziz Abrar Reshid ${ }^{\mathrm{b}}$
}

May 16, 2017

\begin{abstract}
During the first 10 years in the Swedish labor market, male university graduates experience a faster wage growth than their female counterparts. This paper investigates the role of job mobility and upward occupational mobility in explaining the gender gap in early career wage growth. The analysis reveals that although job mobility and upward occupational mobility significantly contribute to the early career wage growth of both men and women, the size of the wage growth effect of both types of mobility is significantly lower for women. This female mobility penalty persists even after accounting for gender differences in observed individual and job characteristics, as well as unobserved individual specific heterogeneity. We further investigate to what extent this mobility penalty of women is explained by parental status. We find that the female penalty in returns to upward occupational mobility is largely linked to the timing of childbirth and childcare, which suggests the presence of a trade-off between work and family. Regarding job mobility, a significant female penalty is found among the childless as well as among parents, and anticipation of parenthood within the next year is found to exacerbate the female penalty in returns to job mobility even further.
\end{abstract}

Keywords: Gender gap, wage growth, job mobility, occupational mobility and children JEL-codes: J13, J16, J31, J62

\footnotetext{
${ }^{a}$ I would like to thank Dan-Olof Rooth, Magnus Carlsson, Dominique Anxo, Peter Skogman Thoursie, Erica Lindahl, seminar participants at Linnaeus University, IFAU and the ESPE 2016 annual conference in Berlin for the valuable comments and suggestions. The author thanks the Institute for Labor Market and Education Policy Evaluation (IFAU) for providing the data needed for this study. All remaining errors are the author's own responsibility.

b Department of Economics and Statistics, Linnaeus University, SE-35195 Växjö, Sweden, e-mail: abdulaziz.abrar@lnu.se
} 


\section{Table of contents}

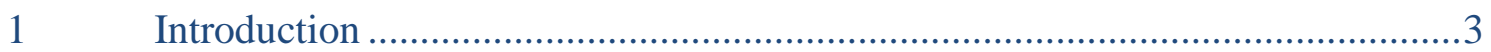

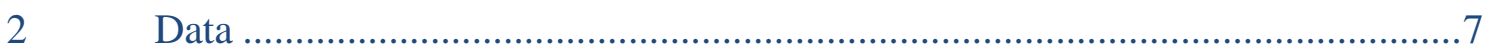

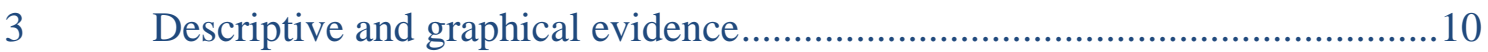

3.1 The dynamics of men's and women's wage over a life cycle..........................10

3.2 Mobility pattern and dynamics of wage growth............................................ 12

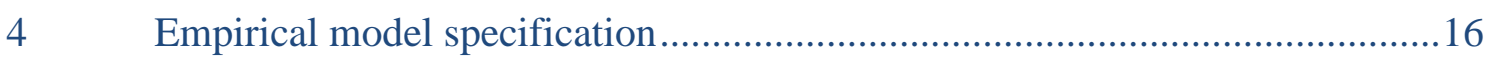

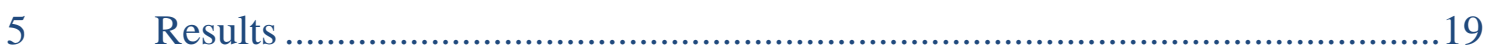

5.1 The gender gap in returns to job and occupational mobility ............................19

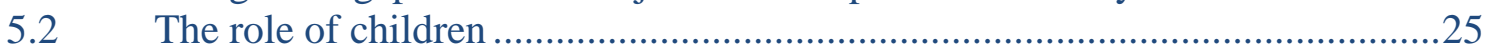

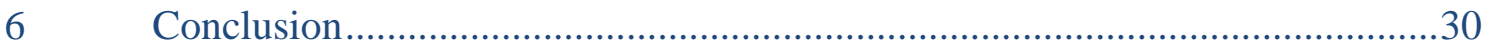

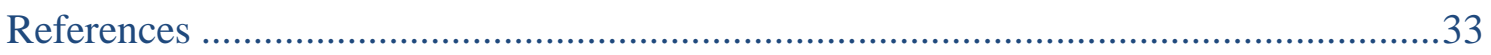

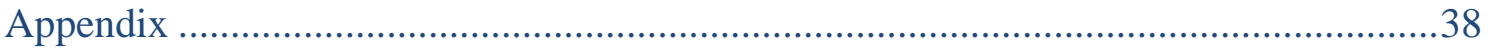




\section{Introduction}

Despite the declining gender wage gap over the past few decades, women continue to earn less than men in most countries (OECD, 2016). This finding is in stark contrast with the tremendous success many countries have had in closing the gender gap in educational attainment, with the high female labor force participation and the legislative effort to guarantee equal pay for equal value of work. In an attempt to understand the persistent gender wage gap, recent advances in the literature analyze the dynamics of the gender wage gap over one's life cycle. These studies often find that although the male-female wage gap is relatively small upon labor market entry, a considerable gender wage gap arises during the first few years after labor market entry (Loprest, 1992; Manning and Swaffield, 2008; Napari, 2009; Del Bono and Vuri, 2011; and Bertrand et al., 2010). Sweden, the focus of this study, is no exception, in which a sizable gender wage gap emerges during the first few years in the labor market. Given that early career wage growth constitutes a considerable part of the lifetime wage growth, an explanation for the gender differential wage growth during professionals' early careers is important for understanding the overall gender wage gap (Loprest, 1992). This paper seeks explanations regarding why Swedish young female university graduates lag behind their male counterparts in terms of the wage growth during the first 10 years after labor market entry.

Traditionally, researchers have focused on human capital explanations based on the unequal division of labor in the household as the main underlying mechanism. It is argued that women with children are more likely to have intermittent labor market attachment, work fewer working hours, are likely to have depreciation of acquired skills and exert less effort in the work place given the additional burden that they have in the household (Mincer and Polachek, 1974; Becker, 1985; Bertrand et al., 2010; Angelov et al., 2016). While this line of explanations continues to be important, a number of studies also show that a sizable gender wage gap remains unexplained after accounting for the gender difference in human capital and a number of job-related factors (Blau and Kahn, 2006; Wood et al., 1993; Manning and Swaffield, 2008; Albrecht et al., 2003).

In contrast to much of the previous literature, this paper focuses on explanations based on job shopping and occupational mobility that have received rather little attention in the literature. Job shopping theories hypothesize that job mobility (firm change) 
is one means through which young workers improve their firm match quality and achieve higher wage growth (Jovanovic, 1979 and Johnson, 1978). Like job mobility, upward occupational mobility is the second channel through which young workers climb the occupational ladder to higher wage levels (McCall, 1990). ${ }^{1}$ However, it is conceivable that women may not benefit as much as men, often for a number of reasons. First, this early stage of young men's and women's careers is also the time to form family and have children. In a society in which women assume the majority of family responsibilities, motherhood may restrict women's job match quality and potential upward occupational move, since women need to consider the non-pecuniary aspects of a job that are in accordance with family commitment. As long as employers reward jobs with attributes that are difficult to reconcile with temporary family commitment, gender differences in returns and/or rates of job and occupational mobility can partly explain the gender gap in early career wage growth (Goldin, 2014). Second, such gender differences can also be fueled by employers' statistical discrimination in hiring and/or promotion if employers perceive that women are more likely to quit their jobs or are less willing to work long hours or travel long distances (Phelps, 1972; Lazear and Rosen, 1990; and Belley et al., 2015). Finally, theories of psychological traits suggest that gender difference in negotiation skills or outcomes can contribute to the gender gap in returns to firm (occupational) change (Bertrand, 2011, Bowles, 2012).

Empirical studies examining the gender differential effect of job and occupational mobility on early career wage growth are relatively scarce. With regard to job mobility, the few studies within the US and Europe that address the issue typically find a substantial gender difference in wage growth returns to job mobility, partly explaining the gender gap in early career wage growth (Loprest, 1992; Manning and Swaffield, 2008; Napari, 2009; Del Bono and Vuri, 2011; Looze, 2014 and Fuller, 2008). Although motherhood is often discussed as the potential underlying factor for gender differential returns to job mobility, most of these studies fail to empirically investigate the issue (Manning and Swaffield, 2008; Looze, 2014 and Fuller, 2008, are the few exceptions). The literature on occupational mobility, on the other hand, largely focuses on the gender difference in the average rate and/or the returns to upward occupational mobility at higher managerial positions (Jacobs, 1992; Bertrand and Hallock 2001; and Magnusson,

\footnotetext{
${ }^{1}$ Upward occupational mobility may arise either through within firm promotion or through firm change.
} 
2010). However, minimal focus has been placed on the pattern and/or returns to upward occupational mobility during the early stage of women's careers (Fitzenberger and Kunze, 2005 and Addison et al., 2014, are among the few exceptions). In Sweden, Le Grand and Tahlin (2002) documented that job mobility across and within firms positively contributes to the early career wage growth of young male workers. However, not much is known regarding how job and occupational mobility affects women's wage growth and to what extent this contributes to the gender gap in early career wage growth.

By using Swedish register panel data for the period 1996-2012, this study examines the role of job and upward occupational mobility in explaining the gender gap in early career wage growth in the Swedish labor market. This paper contributes to the literature in two ways. First, to the author's knowledge, this is the first Swedish study that investigates the link between job mobility, upward occupational mobility and gender difference in early career wage growth of college graduates in the Swedish labor market. ${ }^{2}$ This contribution relates to prior studies on job mobility by Loprest (1992) for the US, and to European studies, such as Manning and Swaffield (2008), Del Bono and Vuri (2011) and Napari (2009). In addition to the literature on job mobility, this paper also contributes to the small strand of literature that analyzes the impact of upward occupational mobility/promotion in early career wage growth (for example, Fitzenberger and Kunze 2005 and Addison et al., 2014). Second, this paper adds to the existing literature by investigating the extent to which the female disadvantage in returns to mobility is explained by motherhood. ${ }^{3}$ In contrast to most prior studies, such as those by Manning and Swaffield (2008), Looze (2014) and Fuller (2008), the availability of information on the exact year of childbirth allows us to analyze the temporary and long-run consequences of childbirth on the gender differential in returns to job and occupational mobility.

\footnotetext{
${ }^{2}$ For Sweden, Magnusson (2010) analyzed the relationship between the gender wage gap and occupational prestige, but the paper focuses on the average wage gap in levels for the entire population. Instead, our study investigates the gender gap in early career wage growth during the first 10 years in the labor market and focuses on university graduates.

${ }^{3}$ In Sweden, a recent study by Hotz, Johansson and Karimi (2017) examines the link between parenthood and firm "family friendliness" in explaining the gender wage gap. Compared to Hotz et al (2017), our study mainly focuses on college graduates, a group that is likely to differ from the population average in terms of gender difference in preference for work,family, and the labor market constraints (e.g. individual wage bargaining could be more common in high skilled jobs).
} 
The focus on university graduates is motivated by a combination of factors. First, in contrast to the evidence for the US, prior studies that analyzed the gender wage gap by educational level documented that the gender wage gap among highly educated workers is higher than among less educated workers in the Swedish labor market (Evertsson et al., 2009). ${ }^{4}$ This finding is surprising, given that women with a college education are better at signaling their long-term career commitment (through investment in higher education) to their employer than less educated women. Hence, it is interesting to examine the factors causing female university graduates to lag behind their male counterparts. Second, due to a lack of information on actual work experience, we use information on the year of university graduation to follow the labor market history from the first year after labor market entry up to 10 years in the labor market. By focusing on university graduates, we can track work history more accurately, since this group is more likely to join the labor market immediately and work continuously. However, using the year of graduation to measure the work history for those who are less educated can be complicated, since it is not obvious if the less educated will begin their career immediately or will continue to pursue higher education after a short break. Lastly, considering the growing share of university graduates in the labor force ${ }^{5}$, understanding the factors behind the gender gap among university graduates can contribute to our understanding of the overall gender gap in Sweden.

The main findings from this study can be summarized as follows. Like the US and other European countries, a considerable gender wage gap arises during the first 10 years in the labor market. We find that the entry gender wage gap increases by approximately 12 percentage points within 10 years after labor market entry, which corresponds to a $1.2 \%$ gender gap in the annual wage growth. The empirical analysis shows that although job mobility and upward occupational mobility significantly contribute to the early career wage growth of both males and females, we find that the returns to both types of mobility are significantly lower for females. This female mobility penalty persists, even after accounting for gender differences in observable individual and job characteristics as well as unobserved individual specific heterogeneity. A classification

\footnotetext{
${ }^{4}$ Albrecht et al. (2003), for instance, documented that the "glass ceiling effect" found in Sweden is mainly driven by white collar workers.

${ }^{5}$ During 1997-2012, the proportion of the population with at least 3 years of post-secondary education increased from $13 \%$ to $25 \%$ (Statistics Sweden).
} 
of job mobility into voluntary and involuntary job mobility shows that the female penalty is mainly driven by voluntary firm changes.

We further explored to what extent women's penalty in returns to voluntary job and upward occupational mobility is explained by parental status. The female penalty in returns to upward occupational mobility is found to be largely linked with the timing of childbirth and childcare, suggesting the presence of a trade-off between work and family commitment. Regarding the female penalty in returns to voluntary job mobility, we find that women who anticipate having the first childbirth next year experience the highest female penalty, suggesting a likely trade-off between women's choice for family-friendly jobs and wage rewards. However, such trade-offs associated with parenthood appears to be not the only explanation as we also find a significant female penalty in returns to voluntary job mobility among the childless who do not expect to have a child at least next year and those who had childbirth 3 or more years ago. Hence, in addition to family considerations, other explanations such as statistical discrimination or gender differences in wage bargaining skills cannot be ruled out.

The remainder of this paper is organized as follows. Section 2 describes the data and explains the variables used in the analysis. Section 3 presents descriptive and graphical evidence of the gender wage gap over time. Section 4 describes the empirical model. Section 5 offers the empirical results, and finally, Section 6 concludes the paper.

\section{Data}

The empirical analysis is based on the panel data constructed from various Swedish register sources obtained from Statistics Sweden covering the 1996-2012 period. We used unique individual-firm identifiers to merge the wage structure statistics with various data sources from individual administrative registers (LOUISE and the multigeneration register) and the firm register. ${ }^{6}$ For the few cases in which an individual

\footnotetext{
${ }^{6}$ The wage structure statistic is a combination of a survey of the wages and salary structure from the public and private sector collected by Statistics Sweden. The statistic for the private sector is based on a random sample survey, which constitutes approximately 50\% the private sector, while the sample for the public sector constitutes the whole population. This database is our main source of information on average wages and job characteristics such as occupation and sector by ownership status. Louise (also known as LISA) is a population-wide longitudinal database and is our main data source on annual income, years and levels of education, potential experience (year of graduation), age, gender and marital status. The multi-generational register links parents with their children and includes information on the year of childbirth and birth order. The firm register includes information on firm identifiers (used to generate the job mobility variable), firm size and industry. The employer-employee register is used to merge individual-based registers with firm-based registers.
} 
works in more than one firm, we consider the individual-firm identifier that generates the highest annual income in a given year. This panel dataset consists of information on an average monthly wage, level and field of education, year of graduation, year of childbirth, firm identifier, occupation and a number of individual and job-related characteristics. Because our main interest is on the early career dynamics of young college graduates, the sample is restricted to young graduates during 1996-2002, and each graduate is followed from the first year after graduation up to 10 years in the labor market. ${ }^{7}$ For example, graduates in 1996 are followed from 1997 to 2006, while graduates in 2002 are followed from 2003 to 2012. PhD graduates and individuals who are older than 35 years in the year of graduation are excluded from the sample. These restrictions are made to exclude individuals who may have prior experience before graduation and focus on graduates who made their first transition from college to work.

The outcome variable of interest, wage growth, is calculated from the average real monthly wage level, expressed in 2010 constant price. These wage data are obtained from the wage structure register, which consists of all individuals employed in the public sector, individuals working in private firms with more than 499 employees and a randomly selected 50\% sample of private-sector employees with a firm size between 10 and 499 employees. The sample excludes individuals working in small firms with less than 10 employees. A consequence of the above random sampling is that wage is observed with gaps, which ultimately creates an unbalanced panel in the annual wage growth. Table 1 below reports the number of gaps between consecutive wage observations for our sample of university graduates. It is apparent that in most of the years, $84 \%$ for women and $91 \%$ for men, wage can be observed in annual basis. However, for about $16 \%$ of women and $9 \%$ of men, the wage is observed with gaps. ${ }^{8}$ Given the unbalanced panel data, defining wage growth as a difference between wage levels at year $t-1$ and $t$ would discount individuals with intermittent wage observations, since one year of missing observations in wage level translates into two years of missing observations in the wage growth. To use as much information as possible, we define wage growth as the difference in real log wage between the current year and the last observed year. That is, wage growth is the difference between wage at time $t$ and time $t-s$, where s represents

\footnotetext{
${ }^{7}$ The analysis in this paper begins from 1996 because this is the year with complete information on the most important variables, primarily occupation.

${ }^{8}$ The gender difference can partly be attributed to the intermittent labor market participation of women due to parental leave taking.
} 
the number of gaps between two subsequent wage observations, which will be added as a control in the main empirical model specification (discussed in Section 4). Since about $98 \%$ of men and women have less than or equal to 3 gaps between wage observations, we restrict our sample to individuals with at most 3 gaps between wage observations. ${ }^{9}$ The final sample consists of an unbalanced 723,752 individual-year observations, of which $61 \%$ are women. ${ }^{10}$

Table 1. Number of gaps between wage observations

\begin{tabular}{lcccc}
\hline & \multicolumn{3}{c}{ Female } & \multicolumn{2}{c}{ Male } \\
\cline { 2 - 5 } $\begin{array}{l}\text { Number of gaps } \\
\text { between wage } \\
\text { observations (s) }\end{array}$ & Percentage & $\begin{array}{c}\text { Cumulative per- } \\
\text { centage }\end{array}$ & $\begin{array}{c}\text { Cumulative per- } \\
\text { centage }\end{array}$ \\
\hline 1 & $(\mathbf{1})$ & $(\mathbf{2})$ & $(3)$ & $(\mathbf{4})$ \\
2 & 83.9 & 83.9 & 91.4 & 91.4 \\
3 & 10.7 & 94.6 & 4.9 & 96.3 \\
4 & 3.0 & 97.6 & 1.4 & 97.8 \\
5 or more & 1.0 & 98.7 & 0.8 & 98.6 \\
\hline
\end{tabular}

Note: In the left side of the table, a one-year gap means that the wage can be observed annually.

There are four explanatory variables of main interest in the empirical analysis. The first is the female dummy, which takes a value of 1 if female and 0 otherwise. The other three key variables are job mobility, upward occupational mobility and parental status. Job mobility is a dummy variable that takes a value of 1 when an individual changes firm between year $t$ and $t-s$. The second variable of interest is upward occupational mobility, which is a dummy variable that takes a value of 1 if an individual attains a $5 \%$ or more increase in occupational prestige scale between year $t$ and $t-s .{ }^{11}$ The prestige scale is measured based on the widely used Standard International Occupational Prestige Scale (SIOPS) of Treiman (1976) and Ganzeboom and Treiman (1996), which largely reflects the degree of authority, skill and capital control of an occupation. The third variable of interest is parental status, which is a dummy that takes a value of 1 if an individual has a child and 0 otherwise. To allow for the non-linear effect of children in the

\footnotetext{
${ }^{9}$ In addition, our sample does not include individuals who are self-employed, since the wage structure statistics do not have wage information on individuals who are self-employed.

${ }^{10}$ One reason for the higher proportion of females in the sample is the greater proportion of females among recent university graduates in Sweden. Second, the $50 \%$ random sampling originates only from the private sector, which is male-dominated and has also contributed to the low male sample.

${ }^{11}$ We choose $5 \%$ instead of simply positive growth in prestige because it can better capture the implied upward move in the degree of autonomy, skill or capital control of the new job position. However, changing the threshold to more than 0 or $10 \%$ does not affect the main conclusion.
} 
model, we further disaggregate parental status into five categories: childless in year $\mathrm{t}$ and $\mathrm{t}+1$ ( $=1$ if no children and not expected to have children in one year's time), will have first child next year, had first child this year, had a child 1-2 years ago (including years between births) and had a child three or more years ago ( $=1$ if the age of the youngest child is greater than two).

In the empirical analysis, we will control for a number of common human capital variables and other individual characteristics. Human capital controls include years of university education (2-5 years) and field of education (9 broad categories of field of study), potential experience (years since graduation), tenure (number of years in the same firm) and gaps with zero annual income (gaps between consecutive wage observations associated with zero annual income). The information on demographic characteristics include marital status ( $=1$ if married) and residence ( $=1$ if living in the four Swedish biggest cities). We also have information on job-related characteristics such as firm size (5 categories), occupation (9 broad categories), industry (14 broad categories) and sector of employment (5 categories by ownership status). The summary statistics for selected variables are reported in Appendix Table A1.

\section{Descriptive and graphical evidence}

\subsection{The dynamics of men's and women's wage over a life cycle}

A typical finding in the US and a few European countries is that a substantial portion of the life cycle gender wage gap arises during the first few years after labor market entry. ${ }^{12}$ This section examines whether similar patterns exist for Sweden by examining the dynamics of the gender wage gap over a worker's life cycle. For the purpose of this analysis, we consider a longer panel data covering the 1990-2012 period for graduate cohorts of 1990-2002. Figure 1 presents the wage level and growth profiles of male and female university graduates from labor market entry to a maximum of 22 years in the labor market. From the wage-experience profile of male and female graduates (Figure 1 ), it is apparent that the gender wage gap is relatively small at labor market entry. However, a sizable gender wage gap emerges within 10 years in the labor market before it begins to stabilize during the mid-career stage. This pattern can be clearly observed

\footnotetext{
${ }^{12}$ An exception in this regard is Germany’s apprenticeship graduates, where Fitzenberger and Kunze (2005) found a substantial gender gap at labor market entry, and this gap persisted over early careers.
} 
from the wage growth profile (Figure 2), which shows that most of the gender wage gap is created during the first 10 years in the labor market. This result is similar to the findings from other US studies and those of European countries.
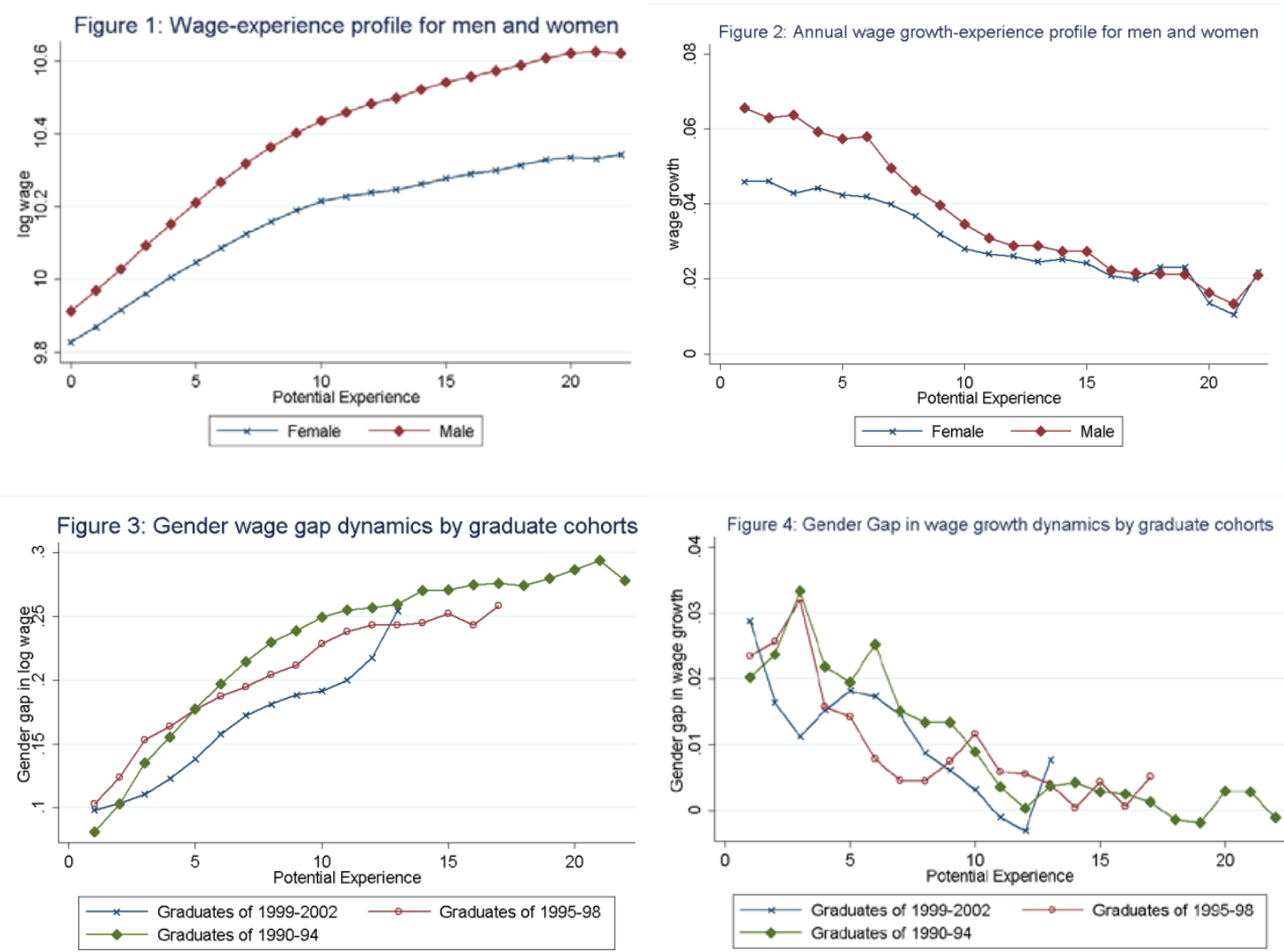

One may be concerned that the above result is driven by the difference in the gender gap among different graduate cohorts. In the above pooled sample, we are not able to follow all of the graduate cohorts of 1990-2002 over 22 years, and therefore part of the wage dynamics can potentially be influenced by differences in the wage dynamics among different graduate cohorts. Figure 3 and Figure 4 show the gender gap dynamics in log wage and wage growth among graduate cohorts of 1990-1994, 1995-1998 and 19992002 separately. A graphical inspection of the above three cohorts, in Figure 3 and Figure 4, shows that our result is not driven by a cohort effect.

Table 2 presents the gender wage gap in numbers from the labor market entry to a maximum of 10 years in the labor market for the graduate cohort used in our main analysis. The result from Column 1 shows that the raw gender wage gap at labor market 
entry is approximately $9 \% .{ }^{13}$ Compared to international studies, this entry gap is higher than that found for the US and the UK, but is comparable with other European countries such as Germany, Finland and Italy. ${ }^{14}$ Immediately after labor market entry, the gender wage gap increases at a decreasing rate, reaching up to $21 \%$ within only 10 years in the labor market. ${ }^{15}$ This gender wage gap dynamic is equivalent to a $1.2 \%$ gender gap in the annual wage growth. This paper is devoted to explaining this gender gap in the wage growth within the following sections.

Table 2. Gender gap in log wage and wage growth by experience

\begin{tabular}{lcc}
\hline & \multicolumn{2}{c}{ Gender Gap in } \\
\cline { 2 - 3 } Potential experience & Log wage & Wage growth \\
\hline 0 (Year of graduation) & $(\mathbf{1})$ & $(2)$ \\
1 & -0.093 & - \\
2 & -0.110 & -0.016 \\
3 & -0.115 & -0.013 \\
4 & -0.125 & -0.015 \\
5 & -0.138 & -0.014 \\
6 & -0.150 & -0.014 \\
7 & -0.167 & -0.015 \\
8 & -0.18 & -0.01 \\
9 & -0.192 & -0.008 \\
10 & -0.200 & -0.008 \\
Average & -0.210 & -0.007 \\
\hline
\end{tabular}

Note: In Column 2, the gender gap at each experience level is estimated after controlling for the gap between wage observations.

\subsection{Mobility pattern and dynamics of wage growth}

This section provides descriptive evidence on the relative importance of gender differences in the rates of and the returns to job and occupational mobility by using graphs and descriptive statistics. First, we examine whether gender differences in annual rates of job and upward occupational mobility are plausible candidates in explaining the observed gender difference in early career wage growth. A visual inspection of Figure 5 below indicates that women tend to change firms more often than men during the first

\footnotetext{
${ }^{13}$ Carlsson et al., 2015 analyzed the gender wage gap at labor market entry by using a combination of register and experimental data and show that pre-labor market factors, particularly the type of college major, explain much of the entry gender wage gap and find no evidence of gender discrimination in hiring.

${ }^{14}$ Bertrand et al., 2010 for US; Manning and Swaffield, 2008 for UK; Fitzenberger and Kunze, 2005 for Germany; Napari, 2009 for Finland; and Del Bono and Vuri, 2011 for Italy.

${ }^{15}$ We also find similar gender wage gap dynamics after controlling for pre-labor market factors (level and field of education, and graduate cohort*year-fixed effects). This finding is reported in Appendix Table A2.
} 
four years in the labor market; however, after four years, the pattern is reversed in favor of men. Over a 10-year average, the annual rate of job mobility (firm change) is similar among men and women, averaging 13.3 and 12.6\%, respectively. Regarding the annual rates of occupational mobility, Figure 6 indicates a gender difference beginning from the second year in the labor market. On average, approximately $6.2 \%$ of women experience upward occupational mobility (at least have a 5\% increase in occupational prestige) annually, which is lower than the men's $7.3 \%$ increase. Hence, in contrast to job mobility, there is a small gender difference in the rates of upward occupational mobility.
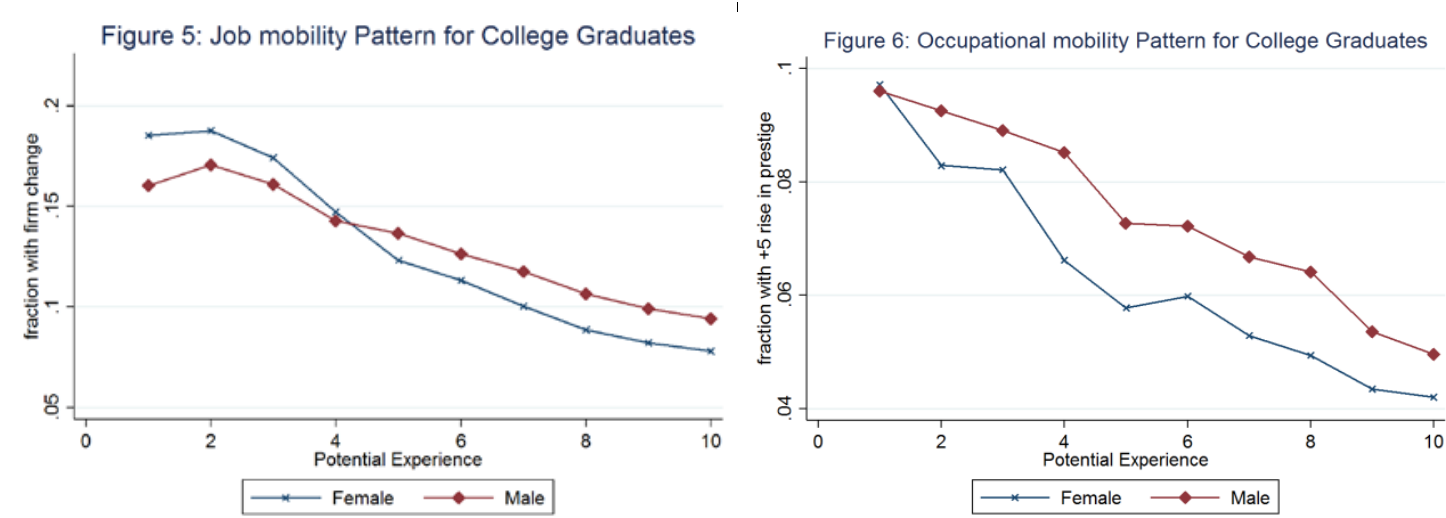

Note: Figure 5 and 6 presents the fraction of college graduates who changed jobs and those who experience upward occupational mobility between year t and t-s (relative to stayers) at each level of potential experience, respectively.

The second step is to examine whether gender differences in returns to job and occupational mobility contribute to gender differences in early career wage growth. Figure 7 reports the returns to job mobility by decomposing the annual wage growth into those who exhibit firm change and those who remained in the same firm. A visual inspection of the wage growth dynamics provides two interesting results. First, both male and female graduates experience higher wage growth when changing firms than without firm change. Second, the magnitude of the male-female gap in the wage growth among those exhibiting firm change is higher than the gap among individuals who remained in the same firm. In Figure 8, we examine the potential contribution of the gender difference in returns to upward occupational mobility after decomposing the wage growth by the occupational mobility status. Like job mobility, we also find higher wage growth associated with upward occupational mobility for both male and female graduates compared to those with no upward occupational mobility. It is also evident from a visual inspection of the wage growth dynamics that the size of the male-female gap among graduates who experienced upward occupational mobility is higher than those without upward 
occupational mobility. The graphical evidence indicates that although job and occupational mobility are important for the early career wage growth of males and females, women appear to benefit to a lesser extent than men.
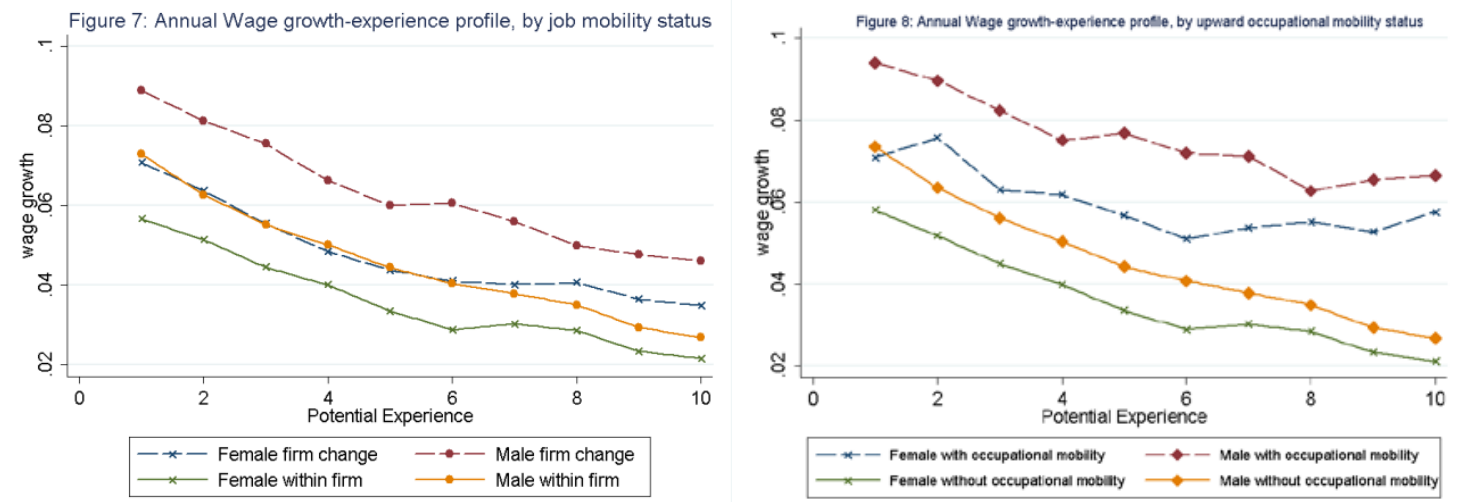

Note: The dashed lines in Figure 7 and 8 represent the wage growth at each level of potential experience for graduates who changed firms and occupational prestige between year $t$ and $t-s$, respectively. The solid lines in Figure 7 and 8 represent the wage growth between year $t$ and t-s within the same firm and occupations, respectively. For ease of interpretation, we reported the annual wage growth by dividing the wage growth by the number of gaps between consecutive observations $\left(\frac{w_{t}-w_{t-s}}{s}\right)$.

Panel B in Table 3 presents similar evidence of returns to job and occupational mobility by gender as in the graphs but presents numbers instead. The table clearly shows that the size of the gender gap in the wage growth among graduates with firm change is $1.4 \%$, which is higher than the $0.9 \%$ wage growth without firm change. Similar results can be found for upward occupational mobility in which the gender gap in the wage growth is higher among those with upward occupational mobility. These results highlight the importance of gender differences in returns to job and upward occupational mobility in explaining the gender gap in early career wage growth.

Parenthood has been suggested as an important underlying mechanism contributing to the gender difference in the effect of job and occupational mobility on early career wage growth. To examine the potential contribution of parental status, we decomposed the rates and returns to mobility by parental status as shown in Columns 4 and 5 of Table 3. From Panel A, Column 4, we find a 1.3\% gender gap in the annual rates of job mobility among childless groups, which shows that childless women change firms more frequently than childless men. However, the situation is reversed after having children, where fathers are found to experience $1.4 \%$ more firm changes than mothers (Column 5). This result suggests that parenthood largely affects the timing of firm changes by gender but not the overall rate of job mobility. Regarding the rates of upward occupa- 
tional mobility, the figures show that the gender gap varies by parental status, where the gender gap in the rates of upward occupational mobility is higher among parents than among childless groups.

Table 3. Descriptive statistics by gender and parental status

\begin{tabular}{|c|c|c|c|c|c|}
\hline \multirow[b]{2}{*}{ Description } & \multicolumn{3}{|c|}{ Total } & \multirow{2}{*}{$\begin{array}{c}\text { Childless } \\
\text { Female- } \\
\text { Male Gap }\end{array}$} & \multirow{2}{*}{$\begin{array}{c}\text { Parent } \\
\text { Female- } \\
\text { Male Gap }\end{array}$} \\
\hline & Female & Male & $\begin{array}{c}\text { Female- } \\
\text { Male Gap }\end{array}$ & & \\
\hline & (1) & $(2)$ & (3) & (4) & (5) \\
\hline \multicolumn{6}{|l|}{ Panel A: Rates of job and occupational mobility } \\
\hline \multicolumn{6}{|l|}{ Average annual proportion of workers: } \\
\hline with firm change & 0.126 & 0.130 & -0.004 & 0.013 & -0.014 \\
\hline with upward occupational mobility & 0.062 & 0.073 & -0.011 & -0.008 & -0.011 \\
\hline \multicolumn{6}{|c|}{ Panel B: Returns to job and occupational mobility ${ }^{a}$} \\
\hline \multicolumn{6}{|l|}{ Average annual wage Growth } \\
\hline with firm change & 0.050 & 0.064 & -0.014 & -0.013 & -0.016 \\
\hline without firm & 0.035 & 0.044 & -0.009 & -0.007 & -0.009 \\
\hline with upward occupational mobility & 0.061 & 0.076 & -0.015 & -0.010 & -0.020 \\
\hline without upward occupational mobility & 0.035 & 0.044 & -0.009 & -0.007 & -0.009 \\
\hline
\end{tabular}

Note: a) For ease of interpretation, we report the annual wage growth by dividing the wage growth by the number of gaps between consecutive observations ( $\frac{w_{t}-w_{t-s}}{s}$ ). This is approximately equal to adding a control for the missing gap between wage observations in the wage growth equation.

Panel B of Columns 4 and 5 reports the gender gap in the annual wage growth by mobility and parental status. The figures on the annual wage growth associated with firm change show that the size of the gender gap in the annual wage growth does not appear to vary by parental status. We find a sizable gender gap in the wage growth among the childless as well as parents. With regard to upward occupational mobility, there are clear signs of a motherhood penalty in the returns to upward occupational mobility, where the gender gap among parents is two times higher than among childless groups (see panel B of Columns 4 and 5 in Table 3).

In sum, the evidence from the graphs and the descriptive statistics suggest that the gender differences in the rates of job and upward occupational mobility are relatively small, but there is a sizable gender difference in returns. Since the gender difference in the rates of mobility is relatively small, our empirical analysis in the next section will primarily focus on the gender difference in the returns to mobility and its contribution to the divergent early career wage growth of male and female graduates. 


\section{$4 \quad$ Empirical model specification}

In this section, we examine the impact of job and occupational mobility on the gender gap in wage growth after accounting for the gender difference in human capital and family- and job-related characteristics. The empirical model specification for wage growth is similar to Loprest (1992), Del Bono and Vuri (2011) and Manning and Swaffield (2008). Compared to the standard log wage equation in first difference, our empirical model specification assumes that time invariant factors such as gender, field and levels of education not only affect the wage level but also the wage growth dynamics. ${ }^{16}$ The model is estimated by pooling the individual-year observations of male and female graduates during the first 10 years in the labor market. The general model specification of the wage growth equation is formulated as follows:

$$
\begin{gathered}
\Delta W_{i t}=\beta_{0}+\beta_{1} F_{i}+\beta_{2} \Delta j o b_{i t}+\beta_{3} \Delta O c c_{i t}+\beta_{4} F_{i} * \Delta j o b_{i t}+\beta_{5} F_{i} * \Delta O c c_{i t}+\emptyset\left(e_{i t}, n_{i t}, g a p_{i t}^{s}, g a p_{i t}^{u}\right)+ \\
X_{i t-s} \beta_{6}+X_{i t} \beta_{7}+Z_{i} \beta_{8}+\varepsilon_{i t}
\end{gathered}
$$

where $\Delta W_{i t}$ represents the change in the monthly log wage of an individual $i$ from year $t-s$ to year $t$ (with $s$ representing the gaps between consecutive wage observations). $\beta_{0}$ is a constant in the wage growth equation, which can be interpreted as a common trend in wage levels. $F_{i}$ is a female dummy, and the corresponding estimate $\beta_{1}$ represents the average gender gap in the wage growth during the first 10 years in the labor market. The variable $\Delta j o b_{i t}$ is a job mobility dummy, which takes a value of 1 if individual $i$ changes firms between year $t$ and $t-s$, and $\Delta O c c_{i t}$ is an occupational mobility dummy, which takes a value of 1 if individual $i$ experiences a $5 \%$ or more increase in the occupational prestige scale between year $t$ and $t-s$. The coefficients $\beta_{2}$ and $\beta_{3}$ represent the change in the wage growth associated with job and occupational mobility, respectively. The coefficients $\beta_{4}$ and $\beta_{5}$ provide the gender difference in the effect of job and occupational mobility on the wage growth.

The function $\emptyset\left(e_{i t}, n_{i t}, g a p_{i t}^{s}, g a p_{i t}^{u}\right)$ includes a measure of human capital accumulation, where $e_{i t}$ is potential experience and $n_{i t}$ is the number of years of tenure in a firm, gap $p_{i t}^{s}$ is the number of gaps between wage observations, and $g a p_{i t}^{u}$ is the number of gaps between wage observations due to unemployment (defined by zero annual labor income).

\footnotetext{
${ }^{16}$ The wage growth equation is derived from a wage level equation where the model includes not only the standard time varying and time invariant factors but also the interaction between time invariant factors (such as gender, field and level of education) with the time trend.
} 
Potential experience and tenure are included in quadratic forms to account for nonlinearity in the wage growth dynamics during the first 10 years in the labor market. The variable $\mathrm{gap}_{i t}^{s}$ is included in linear form and takes into account the gaps between wage observations. ${ }^{17}$ As previously discussed in section 2, most of the gaps between wage observations are missing at random (related to the annual random sampling of the private sector wage data) and are not expected to systematically differ between male and female graduates. However, we noticed that the wage observations for female graduates are missing to a larger extent than for males (in Table 1), which can be attributable to the greater tendency of female workers to have intermittent labor market attachment for family reasons. In this model, we attempted to isolate the latter factors by controlling for the gaps due to zero annual income, $g a p_{i t}^{u}$. This variable is generated based on the information on annual labor income from Statistics Sweden's register data. ${ }^{18}$ In the above model, $Z_{i}$ is the vector of time invariant factors such as years and fields of education; $X_{i t}$ and $X_{i t-s}$ are the vectors of time varying controls at time $\mathrm{t}$ and t-s. The controls in $X$ include demographic characteristics (parental status, marital status and residence), job-related characteristics (firm size, occupation, industry and sector by ownership status), year of graduation $\times$ year fixed effect and $\varepsilon_{i t}$ is the error term.

A methodological concern in a typical cross-sectional regression analysis of wage levels is that job movers/those promoted could be different from stayers/non-promoted in unobservable characteristics that are related to wage levels. ${ }^{19}$ Regarding the wage growth, the first difference in the wage level factors out the individual specific unobserved confounders and allows us to estimate the model using OLS. However, one may also be concerned that current year movers could be different from stayers in unobserved time-varying characteristics that are related to the wage growth. In this paper, we check the robustness of the result by two means. First, we introduce the individual fixed effect to the wage growth equations which account for the individual specific change over time (e.g., changes in labor market effort or commitment). Second, similar to Mincer (1986) and Del Bono and Vuri (2011), we use the next year’s job (occupational)

\footnotetext{
${ }^{17}$ This model is adopted from Manning and Swafield (2008) and Del Bono and Vuri (2011), who also use a similar functional form, with the former using a more flexible model.

${ }^{18}$ We also estimate an alternative model specification where we control for the gaps coinciding with the parental leave benefit, gaps coinciding with less than 100,000 sek annual income, and the interaction between female and gaps. In addition, we examined the result based on a sample with continuous wage observations. However, as will be shown later, the main results are qualitatively similar.

${ }^{19}$ For example, individuals with low wages tend to have more motivation to change jobs than individuals with high wage levels.
} 
movers as a counterfactual for the current year's job (occupational) movers. The main argument is that the unobserved time varying characteristics that are correlated with the mobility decision are likely to be similar for current year and next year movers. The wage growth gain to job (occupational) mobility can then be calculated by comparing the wage growth of the current year's movers with the wage growth of next year's movers (who did not move this year). For the latter approach, the empirical model specification can be formulated as follows:

$$
\begin{aligned}
\Delta W_{i t}= & \beta_{0}+\beta_{1} F_{i}+\beta_{2} \Delta j o b_{i t}+\beta_{3} \Delta j o b_{i t+s}+\beta_{4} F_{i} * \Delta j o b_{i t}+\beta_{5} F_{i} * \Delta j o b_{i t+s}+\beta_{6} \Delta O c c_{i t}+ \\
& \beta_{7} \Delta O c c_{i t+s}+\beta_{8} F_{i} * \Delta O c c_{i t}+\beta_{9} F_{i} * \Delta O c c_{i t+s}+\beta_{10} C_{\text {Controls }}+\varepsilon_{i t}
\end{aligned}
$$

The general functional form of the empirical model specification is similar to model (1), except that this model introduces two dummy variables for next year's job mobility $\left(\Delta j o b_{i t+s}\right)$ and occupational mobility $\left(\Delta O c c_{i t+s}\right)$ status, and the female interactions $F * \Delta j o b_{i t+s}$ and $F * \Delta O c c_{i t+s} . \Delta j o b_{i t+s}$ takes a value of 1 if individual $i$ changes firms at time $\mathrm{t}+1$ but not at year $\mathrm{t}$. Similarly, $\Delta O c c_{i t+s}$ takes a value of 1 if individual $i$ experiences upward occupational mobility at year $\mathrm{t}+\mathrm{s}$ but not at time $\mathrm{t} . F * \Delta j o b_{i t+s}$ and $F * \Delta O c c_{i t+s}$ represent female dummy interactions with next year's job and occupational movers. $\beta_{4}$ represents the gender gap in the wage growth associated with job mobility for current year movers. $\beta_{5}$ represents the gender gap in the wage growth for individuals who will change jobs next year (can be considered as a control group). In a differencein-difference framework, the gender gap in returns to job mobility can then be obtained from $\beta_{4}-\beta_{5}$. Similarly, the gender gap in returns to upward occupational mobility can be calculated by taking the difference of $\beta_{8}-\beta_{9}$. As will be shown later, examination of the results from this model shows that the results from OLS estimation are not driven by unobserved heterogeneity. 


\section{$5 \quad$ Results}

\subsection{The gender gap in returns to job and occupational mobility}

The main interest in this section is to investigate whether gender differences in the return to job and occupational mobility contribute to the gender difference in early career wage growth. However, before estimating the wage growth equation with the two mobility measures, it is interesting to examine how much of the raw gender gap in the wage growth remains unexplained after accounting for basic human capital and other demographic and pre-mobility job characteristics. Column 1 of Table 4 reports a raw gender wage growth gap of $1.1 \%{ }^{20}$ It represents the average of the annual increase in the gender wage gap during the first 10 years in labor market. Adding human capital controls such as level of education, field of education, quadratic potential experience, quadratic tenure, gaps coinciding with zero annual income, and year of graduation $\times$ year fixed effects in Column 2 lowers the gender gap in the wage growth to approximately $0.5 \%$. Among the human capital factors, the gender difference in the field of education is found to be the single most important factor contributing to the gender differential in early career wage growth. ${ }^{21}$ However, adding demographic controls (marital status and the five dummies of parental status), big city residence at time t-s and job characteristics (firm size, industry, occupation and sector by ownership) at time t-s does not affect the gender gap in the wage growth (Column 3). ${ }^{22}$ In line with prior studies, such as Manning and Swafield (2008), nearly half of the gender gap in the wage growth remains unexplained after accounting for basic human capital and initial job characteristics.

In Columns 4 and 5, we estimate the wage growth model by introducing job and occupational mobility and their interaction with the female dummy to investigate whether the gender difference in returns to job and occupational mobility contributes to the gender differential wage growth. From the regression, we note that although job mobility and upward occupational mobility significantly contribute to the early career wage growth of male and female graduates, the size of the effect varies by gender. The results show that job and occupational mobility significantly increase men’s wage

\footnotetext{
${ }^{20}$ Note that the estimates from the log wage difference equation are interpreted as percentage change since the estimates (in log points) are small enough (less than $0.05 \log$ point) to be approximated as percentage.

${ }^{21}$ In other words, this finding implies that the returns to potential experience in the wage levels are higher in maledominated fields of study than in female-dominated fields of study.

${ }^{22}$ In this specification, we did not control for the current period's residence and job characteristics because they can potentially be affected by job mobility or occupational mobility.
} 
Table 4. OLS regressions of wage growth on job and occupational mobility by gender

\begin{tabular}{|c|c|c|c|c|c|c|}
\hline \multirow[b]{2}{*}{ Variables } & \multicolumn{6}{|c|}{ Dependent Variable: log wage(t)-log wage(t-s) } \\
\hline & (1) & $(2)$ & (3) & $(4)$ & $(5)$ & (6) \\
\hline Female & $\begin{array}{c}-0.0112^{\star \star \star} \\
(0.0002)\end{array}$ & $\begin{array}{c}-0.0052^{\star \star \star} \\
(0.0002)\end{array}$ & $\begin{array}{c}-0.0048^{\star \star \star} \\
(0.0002)\end{array}$ & $\begin{array}{c}-0.0046^{\star \star *} \\
(0.0002)\end{array}$ & $\begin{array}{c}-0.0028^{\star \star \star} \\
(0.0002)\end{array}$ & $\begin{array}{c}-0.0025^{\star \star \star} \\
(0.0002)\end{array}$ \\
\hline Job mobility & & & & $\begin{array}{l}0.0139 * * * \\
(0.0006)\end{array}$ & $\begin{array}{l}0.0196 * * * \\
(0.0009)\end{array}$ & $\begin{array}{c}0.0180 * * * \\
(0.0009)\end{array}$ \\
\hline$\times$ Female & & & & & $\begin{array}{c}-0.0093^{\star \star \star} \\
(0.0010)\end{array}$ & $\begin{array}{c}-0.0085^{\star \star *} \\
(0.0010)\end{array}$ \\
\hline Occupational mobility & & & & $\begin{array}{c}0.0261^{\star * *} \\
(0.0007)\end{array}$ & $\begin{array}{c}0.0308^{\star * *} \\
(0.0011)\end{array}$ & $\begin{array}{c}0.0312^{\star * *} \\
(0.0011)\end{array}$ \\
\hline$\times$ Female & & & & & $\begin{array}{c}-0.0084^{\star \star \star} \\
(0.0014)\end{array}$ & $\begin{array}{c}-0.0073^{\star \star \star} \\
(0.0014)\end{array}$ \\
\hline Experience & & $\begin{array}{c}-0.0284^{\star * \star} \\
(0.0013)\end{array}$ & $\begin{array}{c}-0.0274^{\star \star \star} \\
(0.0013)\end{array}$ & $\begin{array}{c}-0.0293^{\star \star \star} \\
(0.0013)\end{array}$ & $\begin{array}{c}-0.0294^{\star \star \star} \\
(0.0013)\end{array}$ & $\begin{array}{c}-0.0294^{\star \star \star} \\
(0.0013)\end{array}$ \\
\hline Experience Square & & $\begin{array}{c}0.0023^{\star \star \star} \\
(0.0001)\end{array}$ & $\begin{array}{c}0.0022^{\star \star \star} \\
(0.0001)\end{array}$ & $\begin{array}{c}0.0023^{\star \star \star} \\
(0.0001)\end{array}$ & $\begin{array}{c}0.0023^{\star \star \star} \\
(0.0001)\end{array}$ & $\begin{array}{c}0.0023^{\star * \star} \\
(0.0001)\end{array}$ \\
\hline Tenure & & $\begin{array}{c}0.0055^{\star \star \star} \\
(0.0002)\end{array}$ & $\begin{array}{c}-0.0054^{\star \star \star} \\
(0.0002)\end{array}$ & $\begin{array}{c}0.0000 \\
(0.0002)\end{array}$ & $\begin{array}{c}0.0000 \\
(0.0002)\end{array}$ & $\begin{array}{c}0.0001 \\
(0.0002)\end{array}$ \\
\hline Tenure Square & & $\begin{array}{l}0.0004^{\star \star \star} \\
(0.00002)\end{array}$ & $\begin{array}{l}0.0004^{\star \star \star} \\
(0.0001)\end{array}$ & $\begin{array}{c}0.0000 \\
(0.0000)\end{array}$ & $\begin{array}{c}0.0000 \\
(0.0000)\end{array}$ & $\begin{array}{l}0.00003^{*} \\
(0.00002)\end{array}$ \\
\hline $\begin{array}{l}\text { \# of gaps with zero } \\
\text { income }\end{array}$ & & $\begin{array}{c}-0.0325^{\star \star \star} \\
(0.0031)\end{array}$ & $\begin{array}{c}-0.0325^{\star \star \star} \\
(0.0031)\end{array}$ & $\begin{array}{c}-0.0264^{\star \star *} \\
(0.0031)\end{array}$ & $\begin{array}{c}-0.0264^{\star \star \star} \\
(0.0031)\end{array}$ & $\begin{array}{l}-0.023^{\star \star \star} \\
(0.0031)\end{array}$ \\
\hline $\begin{array}{l}\text { \# of gap b/n observa- } \\
\text { tions }\end{array}$ & $\begin{array}{c}0.0310 \star \star \star \\
(0.0004)\end{array}$ & $\begin{array}{c}0.0342^{\star \star \star} \\
(0.0004)\end{array}$ & $\begin{array}{c}0.0367^{\star \star \star} \\
(0.0004)\end{array}$ & $\begin{array}{c}0.0339 * \star \star \\
(0.0004)\end{array}$ & $\begin{array}{c}0.0339 * \star \star \\
(0.0004)\end{array}$ & $\begin{array}{c}0.0327^{\star \star \star} \\
(0.0004)\end{array}$ \\
\hline $\begin{array}{l}\text { Controls } \\
\text { Years and field of edu- } \\
\text { cation } \\
\text { Parental and marital }\end{array}$ & No & Yes & Yes & Yes & Yes & Yes \\
\hline $\begin{array}{l}\text { status } \\
\text { Graduate cohort xvear }\end{array}$ & No & Yes & $\begin{array}{l}\text { Yes } \\
\text { Yoe }\end{array}$ & $\begin{array}{l}\text { Yes } \\
\text { Yes }\end{array}$ & $\begin{array}{l}\text { Yes } \\
\text { Yes }\end{array}$ & $\begin{array}{l}\text { Yes } \\
\text { Yes }\end{array}$ \\
\hline $\begin{array}{l}\text { Job characteristics at t- } \\
\mathrm{s}\end{array}$ & No & No & Yes & Yes & Yes & Yes \\
\hline Big city at t-s & No & No & Yes & Yes & Yes & Yes \\
\hline Job characteristics at $\mathrm{t}$ & No & No & No & No & No & Yes \\
\hline Big city at $t$ & No & No & No & No & No & Yes \\
\hline Constant & $\begin{array}{c}0.0478^{\star \star \star} \\
(0.0002)\end{array}$ & $\begin{array}{c}0.0810 \star \star \star \\
(0.0021)\end{array}$ & $\begin{array}{l}0.0549 \star \star \star \\
(0.0124)\end{array}$ & $\begin{array}{c}0.0411^{\star \star \star} \\
(0.0121)\end{array}$ & $\begin{array}{l}0.0410 * \star \star \\
(0.0121)\end{array}$ & $\begin{array}{c}0.0318 \\
(0.0223)\end{array}$ \\
\hline Observations & 723,752 & 723,752 & 723,752 & 723,752 & 723,752 & 723,752 \\
\hline R-squared & 0.018 & 0.066 & 0.071 & 0.076 & 0.077 & 0.087 \\
\hline
\end{tabular}

Note: The control for job characteristics at t-s include: firm size (5 categories), sector by ownership (5 categories), industry (14 categories) and occupation (single digit). The job characteristics control on year t excludes occupation due to its high correlation to the occupational prestige status. Parental status consists of five dummies classified by years since birth. The standard errors in parentheses are robust standard errors with clustering at the individual level. $* * * \mathrm{p}<0.01, * * \mathrm{p}<0.05, * \mathrm{p}<0.1$

growth by about 2 and 3.1\%, respectively, while the women's wage growth associated with job and occupational mobility is 0.9 and $0.8 \%$, respectively, lower than that of men. In other words, women experience half and three-fourths of the wage growth that 
men experience when changing firms and moving up the occupational ladder, respectively. The unexplained gender gap, on the other hand, dropped from 0.46 to 0.28 percent. This finding indicates that about 0.18 percentage point (16\%) of the $1.12 \%$ raw gender gap in annual wage growth is attributable to the gender difference in returns to job and occupational mobility. After 10 years in the labor market, this result implies that approximate 1.8 percentage points (16\%) of the $11.2 \%$ gender wage gap in levels can be attributable to the gender difference in returns to job and occupational mobility. ${ }^{23}$ Adding the current year's job characteristics and residence does not affect the main conclusion (Column 6). ${ }^{24}$

Table 5 presents the estimates based on the FE model and the OLS regression of Equation 2 to examine whether our result is robust to unobserved individual heterogeneity. Column 1 reports the estimates from the wage growth equation after controlling for individual fixed-effect and the full model controls listed in Column 6 of Table 4. The results show a qualitatively similar result as in the OLS regression in which we find a significant gender gap in returns to job and upward occupational mobility. This result indicates that our finding is unlikely to be driven by unobserved individual-specific changes over time. Column 2 estimates Equation 2 in which this year's wage growth of next year's job (occupational) movers is used as a proxy for the forgone wage growth of this year's job (occupational) movers. The gender gap in returns to job (occupational) mobility is then calculated by taking the difference in returns between this year's movers and next year's movers. The results show a significant gender gap in returns to job and occupational mobility, amounting to about 0.7 and 0.5 percent, respectively. These results are close to our estimates from the OLS regression in Column 6 of Table 4 as well as the fixed effect model in Column 1. This exercise suggests that our result is unlikely to be driven by unobserved time-varying heterogeneity.

\footnotetext{
${ }^{23}$ The 1.8 percentage point is obtained by cumulating the annual gender gap in wage growth that is attributable to the gender difference in returns to job and occupational mobility over 10 years $\left(0.18^{*} 10\right.$ years). Similarly, the 11.2 percentage point is obtained by cumulating the raw gender gap in annual wage growth over 10 years (from column 1 of Table 4).

${ }^{24}$ In Appendix Table A3, we explore different model specifications where the variable on the number of gaps between wage observations is allowed to vary by reasons for the gaps and by gender. To the model in Column 6 of Table 4, we add controls for gaps coinciding with the receipt of parental leave benefits, gaps coinciding with annual labor income below 100,000 SEK (which is below the full-time annual income for most high skilled workers) and the interaction between gaps and the female dummy. In addition, we examine the result by restricting the analysis to a sample with continuous wage observations (no gaps). The results in Appendix Table A3 show that our results are qualitatively similar.
} 
Table 5. Gender gap in wage growth using fixed effect and alternative model specifications

\begin{tabular}{|c|c|c|}
\hline \multirow[b]{3}{*}{ Variables } & \multicolumn{2}{|c|}{ Dependent Variable: log wage(t)-log wage(t-s) } \\
\hline & (1) & $(2)$ \\
\hline & FE & OLS \\
\hline \multirow[t]{2}{*}{ Female } & & $-0.002^{\star \star \star}$ \\
\hline & & $(0.000)$ \\
\hline \multirow[t]{2}{*}{ Job mobility } & $0.019 * \star \star$ & $0.017^{\star \star \star}$ \\
\hline & $(0.001)$ & $(0.001)$ \\
\hline \multirow[t]{2}{*}{$\times$ female } & $-0.008^{\star \star \star}$ & $-0.009 * \star \star$ \\
\hline & $(0.001)$ & $(0.001)$ \\
\hline \multirow[t]{2}{*}{ Occupational mobility } & $0.025^{\star \star \star}$ & $0.031 * \star \star$ \\
\hline & $(0.001)$ & $(0.001)$ \\
\hline \multirow[t]{2}{*}{$\times$ female } & $-0.005^{\star \star \star}$ & $-0.007^{\star \star \star}$ \\
\hline & $(0.001)$ & $(0.001)$ \\
\hline \multirow[t]{2}{*}{ Job mobility next period } & & $-0.004^{\star \star \star}$ \\
\hline & & $(0.001)$ \\
\hline \multirow[t]{2}{*}{$\times$ female } & & $-0.002^{\star \star}$ \\
\hline & & $(0.001)$ \\
\hline \multirow[t]{2}{*}{ Occupational mobility next period } & & 0.000 \\
\hline & & $(0.001)$ \\
\hline \multirow[t]{2}{*}{$\times$ female } & & $-0.002^{*}$ \\
\hline & & $(0.001)$ \\
\hline \multicolumn{2}{|c|}{ (Job mobility $\times$ female $)-($ Job mobility next period $\times$ female $)$} & $-0.007^{\star \star \star}$ \\
\hline \multirow{4}{*}{\multicolumn{2}{|c|}{$\begin{array}{l}\text { (Occupational mobility } \times \text { female })-(\text { Occupational mobility next } \\
\text { riod } \times \text { female) }\end{array}$}} & $(0.001)$ \\
\hline & & \\
\hline & & $-0.005^{\star \star \star}$ \\
\hline & & $(0.002)$ \\
\hline Observations & 723,752 & 676,062 \\
\hline R-squared & 0.066 & 0.090 \\
\hline Number of id & 122,390 & \\
\hline
\end{tabular}

\subsubsection{Firm change, between- and within-firm occupational mobility}

In this study, we use standard definitions of job and occupational mobility to obtain a comparable result with other international studies. However, since a portion of the upward occupational mobility can be the result of firm change, one may wonder whether the female penalty in returns to upward occupational mobility is driven by a female penalty with firm change but not within the same firm. ${ }^{25}$ To investigate this possibility, we decomposed the two mobility variables into firm change (job mobility without oc-

\footnotetext{
${ }^{25}$ Fryer (2007), for instance, argues that if asymmetric information about male and female productivity is the main reason for employer discrimination against women, we would expect no gender gap in returns to internal occupational promotion; we would only expect gender gaps in occupational promotions with firm change.
} 
cupational mobility), occupational mobility within firm (often referred to as promotion) and occupational mobility with firm change.

Table 6. Gender gap in wage growth by firm change, occupational mobility between and within firms

\begin{tabular}{|c|c|c|c|c|c|}
\hline \multirow[b]{2}{*}{ Variables } & \multicolumn{5}{|c|}{ Dependent Variable: log wage(t)-log wage(t-s) } \\
\hline & (1) & (2) & (3) & (4) & (5) \\
\hline Female & $\begin{array}{c}-0.0048^{\star * *} \\
(0.000)\end{array}$ & $\begin{array}{c}-0.0040 \text { *** } \\
(0.000)\end{array}$ & $\begin{array}{c}-0.0035^{\star * *} \\
(0.000)\end{array}$ & $\begin{array}{c}-0.0028^{\star * *} \\
(0.000)\end{array}$ & $\begin{array}{c}-0.0025^{\star \star *} \\
(0.000)\end{array}$ \\
\hline Firm change only & & $\begin{array}{c}0.0044^{* * *} \\
(0.001)\end{array}$ & $\begin{array}{c}0.0053^{\star * *} \\
(0.001)\end{array}$ & $\begin{array}{c}0.0167^{* * *} \\
(0.001)\end{array}$ & $\begin{array}{c}0.0148^{\star * *} \\
(0.001)\end{array}$ \\
\hline$\times$ Female & & $\begin{array}{c}-0.0075^{\star \star *} \\
(0.001)\end{array}$ & $\begin{array}{c}-0.0080^{\star \star *} \\
(0.001)\end{array}$ & $\begin{array}{c}-0.0089 * \star \star \\
(0.001)\end{array}$ & $\begin{array}{c}-0.0082^{\star \star \star} \\
(0.001)\end{array}$ \\
\hline Occupational mobility within firm & & & $\begin{array}{c}0.0224^{\star \star \star} \\
(0.001)\end{array}$ & $\begin{array}{c}0.0252^{\star \star \star} \\
(0.001)\end{array}$ & $\begin{array}{c}0.0254^{\star \star \star} \\
(0.001)\end{array}$ \\
\hline$\times$ Female & & & $\begin{array}{c}-0.0083^{\star * *} \\
(0.001)\end{array}$ & $\begin{array}{c}-0.0084^{\star * *} \\
(0.001)\end{array}$ & $\begin{array}{c}-0.0077^{* \star *} \\
(0.001)\end{array}$ \\
\hline Occupational mobility with firm change & & & & $\begin{array}{c}0.0607^{\star * *} \\
(0.002)\end{array}$ & $\begin{array}{c}0.0605^{\star \star \star} \\
(0.002)\end{array}$ \\
\hline$\times$ Female & & & & $\begin{array}{c}-0.0182^{\star \star *} \\
(0.003)\end{array}$ & 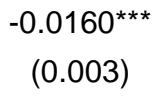 \\
\hline Controls & & & & & \\
\hline Pre-mobility controls at t-s ${ }^{1}$ & Yes & Yes & Yes & Yes & Yes \\
\hline Job characteristics and city at $\mathrm{t}^{2}$ & No & No & No & No & Yes \\
\hline Constant & $\begin{array}{c}0.0549 * \star * \\
(0.0124)\end{array}$ & $\begin{array}{c}0.0557^{\star \star *} \\
(0.0124)\end{array}$ & $\begin{array}{c}0.0558^{\star \star \star} \\
(0.0124)\end{array}$ & $\begin{array}{c}0.0419 * \star * \\
(0.0120)\end{array}$ & $\begin{array}{c}0.0340 \\
(0.0223)\end{array}$ \\
\hline Observations & 723,752 & 723,752 & 723,752 & 723,752 & 723,752 \\
\hline R-squared & 0.071 & 0.071 & 0.072 & 0.077 & 0.088 \\
\hline
\end{tabular}

Note: 1) The pre-mobility controls at t-s include years of education, field of education, quadratic experience, quadratic tenure, gaps between observation and gaps coinciding with zero annual income, parental status, marital status, occupations at t-s, firm size at t-s, sector by ownership at t-s, industry at t-s and residence in big city at t-s and year of graduation $\times$ year dummy. 2) Job characteristics and city controls at t include firm size at t, sector by ownership at $t$, industry at $t$ and residence in big city at $t$. The job characteristics control at $t$ excludes occupation due to its high correlation to the occupational prestige status. The standard errors in parentheses are robust standard errors with clustering at the individual level. $* * * \mathrm{p}<0.01, * * \mathrm{p}<0.05, * \mathrm{p}<0.1$.

Table 6 reports the estimates based on the new classification of the two mobility variables. The first column simply reports the $0.48 \%$ gender gap in the wage growth from Column 3 of Table 4, which remained unexplained after controlling for the pre-mobility characteristics. Column 2 shows that the introduction of firm change with its female interaction reduces the unexplained gender gap from 0.48 to $0.40 \%$. Adding controls for occupational mobility within firm and with firm change in Columns 3 and 4 further reduces the unexplained gender gap to 0.35 and $0.28 \%$, respectively. This result suggests that all three mobility factors are important for explaining the gender gap in the early 
career wage growth. In Column 5, we add the current year's job characteristics and residence. Examining the female interactions with the three mobility variables in Column 5, we find a significant gender difference not only in the returns to firm change and occupational mobility with firm change but also in the returns to occupational mobility within the firm (promotion). This finding indicates that the female penalty in upward occupational mobility is not entirely driven by firm change.

\subsubsection{The role of voluntary and involuntary Job mobility}

With regard to job mobility, prior studies such as Keith and McWilliams (1997) argue that the effect of job mobility may differ depending on the reason for job separation. For example, studies have shown that voluntary employee-initiated job mobility (primarily for career advancement) has a positive effect on wage growth, but employer-initiated non-voluntary job mobility (such as worker layoff or redundancy) is found to have a negative effect on wage growth (Bartel and Borjas, 1981). In the presence of gender differences in the reasons for mobility, estimates that do not consider the gender difference in the types of job mobility could be misleading (Keith and McWilliams, 1997).

Since information on the reasons for firm change is not available, we instead use information on the firm size of the previous employer to identify involuntary layoffs. A firm change is considered involuntary (due to layoff or redundancy) if a previous employer's firm size shrinks by more than $25 \%$ at time t and/or t-s; otherwise, the job mobility is considered voluntary. In general, voluntary job mobility is expected to arise due to career aspirations or family reasons; however, due to data limitation, we are not able to exclude the involuntary firm changes associated with being fired from work. Table 7 presents the OLS and fixed-effect estimates on the impact of voluntary and involuntary job mobility. As one would expect, voluntary job mobility is found to have a significant and positive effect on wage growth, but involuntary job mobility is found to have no significant effect on wage growth. It is also apparent that the gender gap in returns to voluntary job mobility is higher in favor of men. However, women appear to have an advantage regarding involuntary job mobility. ${ }^{26}$ This exercise suggests that the observed gender difference in returns to job mobility is mainly driven by voluntary job mobility.

\footnotetext{
${ }^{26}$ Nevertheless, due to the small share of males and females with involuntary job mobility, its overall effect on the gender gap in wage growth is low.
} 
Table 7 . Gender gap in wage growth by voluntary and involuntary job mobility

\begin{tabular}{|c|c|c|}
\hline & OLS & FE \\
\hline Variables & (1) & (2) \\
\hline \multirow[t]{2}{*}{ Female } & $-0.003^{\star \star \star}$ & \\
\hline & $(0.000)$ & \\
\hline \multirow[t]{2}{*}{ Voluntary Job mobility } & $0.021^{\star \star \star}$ & $0.023^{\star \star \star}$ \\
\hline & $(0.001)$ & $(0.001)$ \\
\hline \multirow[t]{2}{*}{$\times$ Female } & $-0.011^{\star \star \star}$ & $-0.011^{\star \star \star}$ \\
\hline & $(0.001)$ & $(0.001)$ \\
\hline \multirow[t]{2}{*}{ Non-voluntary job mobility } & 0.001 & -0.001 \\
\hline & $(0.002)$ & $(0.002)$ \\
\hline \multirow[t]{2}{*}{$\times$ Female } & $0.008^{\star \star \star}$ & $0.011^{\star \star *}$ \\
\hline & $(0.003)$ & $(0.003)$ \\
\hline \multirow[t]{2}{*}{ Occupational mobility } & $0.031 * \star \star$ & $0.025^{\star \star \star}$ \\
\hline & $(0.001)$ & $(0.001)$ \\
\hline \multirow[t]{2}{*}{$\times$ Female } & $-0.007^{\star \star \star}$ & $-0.005^{\star \star \star}$ \\
\hline & $(0.001)$ & $(0.001)$ \\
\hline \multirow[t]{2}{*}{ Constant } & 0.032 & 0.015 \\
\hline & $(0.022)$ & $(0.032)$ \\
\hline Observations & 723,752 & 723,752 \\
\hline R-squared & 0.088 & 0.067 \\
\hline Number of id & & 122,390 \\
\hline
\end{tabular}

\subsection{The role of children}

The analysis in the previous section demonstrated that returns to job and occupational mobility vary by gender, which partly contributes to the overall gender disparity in early career wage growth. We also find that the female penalty in returns to job mobility is mainly driven by voluntary job mobility. The follow-up question that we are interested in investigating is whether the women's voluntary job and occupational mobility penalty is explained by children. Given the timing of childbirth and childcare coinciding with periods of high mobility, such gender differential outcomes of job and occupational mobility can be related to women's greater responsibility for childcare in the household. This line of explanations is largely derived from the theory of compensating wage differentials, where it can be argued that women, taking greater responsibility for childbearing and childcare, may be willing/forced to forgo wages for the non-pecuniary aspects of a job when changing firms or occupational positions (Joshi et al., 1999). 
To analyze the potential role of motherhood on the gender differential returns to mobility, we disaggregated voluntary job and occupational mobility by parental status. To control for the gender differential effects of parental status that are not associated with mobility status, we added the interaction between parental status and a female dummy as a control in the empirical model. In addition to the above changes, the full model controls used in Column 6 of Table 4 are added to the wage growth equation.

Table 8. Gender gap in returns to job and occupational mobility by parental status

\begin{tabular}{|c|c|c|}
\hline & OLS & FE \\
\hline Variables & $(1)$ & $(2)$ \\
\hline \multicolumn{3}{|l|}{ Occupational mobility } \\
\hline \multirow[t]{2}{*}{ Childless } & $0.029 * \star \star$ & $0.022^{\star \star \star}$ \\
\hline & $(0.001)$ & $(0.002)$ \\
\hline \multirow[t]{2}{*}{ Childless $\times$ Female } & $-0.004^{\star *}$ & -0.003 \\
\hline & $(0.002)$ & $(0.002)$ \\
\hline \multirow[t]{2}{*}{ Parent } & $0.034^{\star \star \star}$ & $0.029 * \star \star$ \\
\hline & $(0.002)$ & $(0.002)$ \\
\hline \multirow[t]{2}{*}{ Parent $\times$ Female } & $-0.011^{\star \star \star}$ & $-0.008^{\star \star \star}$ \\
\hline & $(0.002)$ & $(0.002)$ \\
\hline \multicolumn{3}{|l|}{ Voluntary Job mobility } \\
\hline \multirow[t]{2}{*}{ Childless } & 0.020 *** & $0.021^{\star \star \star}$ \\
\hline & $(0.001)$ & $(0.001)$ \\
\hline \multirow[t]{2}{*}{ Childless $\times$ Female } & $-0.010^{\star \star \star}$ & $-0.010 * \star *$ \\
\hline & $(0.001)$ & $(0.001)$ \\
\hline \multirow[t]{2}{*}{ Parent } & $0.018^{* \star *}$ & $0.020^{* \star *}$ \\
\hline & $(0.001)$ & $(0.001)$ \\
\hline \multirow[t]{2}{*}{ Parent $\times$ Female } & $-0.009 \star \star \star *$ & $-0.008^{\star * *}$ \\
\hline & $(0.001)$ & $(0.002)$ \\
\hline \multirow[t]{2}{*}{ Female } & $-0.002^{\star \star \star}$ & \\
\hline & $(0.000)$ & \\
\hline \multirow[t]{2}{*}{ Constant } & 0.032 & 0.014 \\
\hline & $(0.022)$ & $(0.033)$ \\
\hline Observations & 723,752 & 723,752 \\
\hline R-squared & 0.087 & 0.066 \\
\hline Number of individuals & & 122,390 \\
\hline
\end{tabular}

Table 8 presents the estimates on the wage growth effects of voluntary job and occupational mobility by gender and parental status. Examining the estimates for occupational mobility in Column 1, we find that the gender gap in returns to occupational mobility is higher among parents (1.1\% at the $1 \%$ significance level) than among childless employ- 
ees ( $0.4 \%$ at $5 \%$ significance level). The gender gap among the childless becomes insignificant once we control for the individual-fixed effect in Column 2. However, the gender gap among parents remains high and significant. This result suggests that the women's penalty associated with occupational mobility is largely linked to the motherhood wage penalty. However, regarding the voluntary job mobility, the gender difference in returns to voluntary job mobility is similar among parents and the childless, which is 1 and $0.9 \%$, respectively (Column 1 ). Adding an individual-fixed effect to the wage growth equation does not alter the result (Column 2).

Nevertheless, the above classification of parental status does not take into account the different stages of parenthood, which may have different effects on women's job choices, market constraints and wage growth. We address this issue by disaggregating parental status into five categories: childless (childless and not expecting to have children within one year), will have first child next year, year of first childbirth, had a child 1-2 years ago (including years between births) and had a child 3 or more years ago. If family consideration is the primary explanation, then the female penalty is expected to increase as we get closer to the year of childbirth and childcare and is expected decline as the years since last birth increases.

Table 9 reports the OLS and FE estimates on the impact of voluntary job and occupational mobility on the wage growth by gender and parental status (five categories). ${ }^{27}$ First, examining the estimates on the interaction between the occupational mobility and the female dummy, in Column 1, we find that the size of the female penalty is high and significant among graduates who had their first child this year and graduates who had their child 1-2 years ago (including the time between births). However, the female penalty among the childless and those who had a child 3 or more years ago is low and borderline significant. In fact, the evidence for these latter groups is weak if one examines the estimates from the fixed-effect model in Column 2. One can observe that the gender gap in returns to upward occupational mobility is low and insignificant among the childless, those who will have their first child next year and those who had a child 3 or more years ago (see column 2). On the other hand, the female penalty among graduates who had their first child this year and graduates who had their child 1-2 years ago is large

\footnotetext{
${ }^{27}$ In Appendix Table A4 and Table A5, we also explore different model specifications where the variable on the number of gaps between wage observations is allowed to vary by reasons for the gaps and by gender. However, the main result is qualitatively similar.
} 
and significant (see column 2). This result strengthens our earlier conclusion that the women's penalty to occupational mobility is largely related to the motherhood wage growth penalty during childbirth and childcare periods.

Regarding voluntary job mobility, the disaggregation of parental status reveals additional information. Although the female penalty of voluntary job mobility is persistent for all categories, the female penalty is found to be the highest among graduates who expect to have their first child next year (Column 1 of Table 9). As shown in the fixedeffects model in Column 2, this evidence is robust after controlling for unobserved individual heterogeneity. This finding indicates that anticipation of parenthood in the near future may influence women's job mobility decisions differently than men’s. For example, a recent Swedish study by Hotz et al (2017) documented that women's tendency to move to a family friendly job increases as they get closer to the year of first birth (starting from two years before first birth) and onwards. ${ }^{28}$ Hence, the high female penalty one year prior to first birth is likely to be explained by anticipation of parenthood within a year, in which women may be willing to forgo wage increases for family-friendly jobs.

However, the presence of a significant female penalty among the childless who do not expect to have children within one year and those who had a child 3 or more years ago suggest that the explanation based on the theory of compensating wage differentials (trade-off between women's choice for family-friendly jobs and wage rewards) may not be the full explanation. If family consideration is the only explanation, then we would have at least expected an increase in the female penalty in returns to voluntary job mobility as we move to the years of childbirth and childcare and a decline as the years since last birth increase. However, we find a comparable female penalty for the childless (at $t$ and $t+1)$, parents with young children (1-2 years) and parent with older Table 9. Gender gap in returns to job and occupational mobility by years since birth

\begin{tabular}{lcc}
\hline & OLS & FE \\
\cline { 2 - 3 } VARIABLES & $\mathbf{( 1 )}$ & $\mathbf{( 2 )}$ \\
\hline Occupational mobility & & \\
Childless (at $t$ and $t+1)$ & $0.028^{\star \star \star}$ & $0.022^{\star \star \star}$ \\
& $(0.002)$ & $(0.002)$ \\
$\times$ Female & $-0.004^{\star \star}$ & -0.003 \\
& $(0.002)$ & $(0.002)$ \\
\hline \hline
\end{tabular}

${ }^{28}$ It is, however, important to note that highly educated individuals, the focus in this study, are more constrained to move to a "family friendly" firm, since these firms are characterized by higher share of low skilled workers, as shown by Hotz etal (2017). While the firms that are considered to be less "family friendly" are characterized by high share of high skilled workers. 


\begin{tabular}{|c|c|c|}
\hline & OLS & FE \\
\hline VARIABLES & (1) & (2) \\
\hline \multirow[t]{2}{*}{ Will have first child next year } & $0.026^{\star \star \star}$ & $0.019 * \star \star$ \\
\hline & $(0.004)$ & $(0.004)$ \\
\hline \multirow[t]{2}{*}{$\times$ Female } & -0.001 & 0.002 \\
\hline & $(0.005)$ & $(0.006)$ \\
\hline \multirow[t]{2}{*}{ Year of $1^{\text {st }}$ birth } & $0.033^{\star * \star}$ & $0.027^{\star \star \star}$ \\
\hline & $(0.004)$ & $(0.005)$ \\
\hline \multirow[t]{2}{*}{$\times$ Female } & $-0.027^{\star \star \star}$ & $-0.028^{\star \star \star}$ \\
\hline & $(0.007)$ & $(0.008)$ \\
\hline \multirow[t]{2}{*}{ Had a child $1-2$ years age } & $0.033^{\star * \star}$ & $0.027^{\star \star \star}$ \\
\hline & $(0.002)$ & $(0.002)$ \\
\hline \multirow[t]{2}{*}{$\times$ Female } & $-0.013^{\star \star \star}$ & $-0.010^{\star \star \star}$ \\
\hline & $(0.003)$ & $(0.003)$ \\
\hline \multirow[t]{2}{*}{ Had a child 3 or more years ago } & $0.037^{\star \star \star}$ & $0.033^{\star \star \star}$ \\
\hline & $(0.003)$ & $(0.003)$ \\
\hline \multirow[t]{2}{*}{$\times$ Female } & $-0.006^{*}$ & -0.005 \\
\hline & $(0.003)$ & $(0.004)$ \\
\hline \multicolumn{3}{|l|}{ Voluntary Job mobility } \\
\hline \multirow[t]{2}{*}{ Childless (at $t$ and $t+1$ ) } & $0.022^{\star \star \star}$ & $0.024^{\star \star \star}$ \\
\hline & $(0.001)$ & $(0.001)$ \\
\hline \multirow[t]{2}{*}{$\times$ Female } & $-0.012^{\star \star \star}$ & $-0.013^{\star \star \star}$ \\
\hline & $(0.002)$ & $(0.002)$ \\
\hline \multirow[t]{2}{*}{ will have first child next year } & $0.024^{\star \star \star}$ & $0.026^{\star \star \star}$ \\
\hline & $(0.004)$ & $(0.004)$ \\
\hline \multirow[t]{2}{*}{$\times$ Female } & 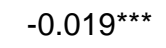 & 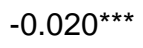 \\
\hline & $(0.004)$ & $(0.004)$ \\
\hline \multirow[t]{2}{*}{ Year of $1^{\text {st }}$ birth } & $0.021^{\star \star \star}$ & $0.025^{\star \star *}$ \\
\hline & $(0.003)$ & $(0.004)$ \\
\hline \multirow[t]{2}{*}{$\times$ Female } & -0.009 & -0.008 \\
\hline & $(0.005)$ & $(0.006)$ \\
\hline \multirow[t]{2}{*}{ Had a child $1-2$ years ago } & 0.018 *** & 0.020 *** \\
\hline & $(0.002)$ & $(0.002)$ \\
\hline \multirow[t]{2}{*}{$\times$ Female } & $-0.008^{\star \star \star}$ & $-0.007^{\star \star \star}$ \\
\hline & $(0.002)$ & $(0.002)$ \\
\hline \multirow[t]{2}{*}{ Had a child 3 or more years ago } & $0.014^{\star \star \star}$ & $0.016^{\star \star \star}$ \\
\hline & $(0.002)$ & $(0.003)$ \\
\hline \multirow[t]{2}{*}{$\times$ Female } & $-0.008^{\star \star \star}$ & $-0.005^{\star}$ \\
\hline & $(0.003)$ & $(0.003)$ \\
\hline \multirow[t]{2}{*}{ Female } & $-0.002^{\star \star \star}$ & - \\
\hline & $(0.000)$ & - \\
\hline \multirow[t]{2}{*}{ Constant } & 0.033 & 0.014 \\
\hline & $(0.022)$ & $(0.033)$ \\
\hline Observations & 723,752 & 723,752 \\
\hline R-squared & 0.088 & 0.067 \\
\hline Number of individuals & & 122,390 \\
\hline
\end{tabular}

Note: The full model controls that are listed in Column 6 of Table 4 are included. In addition, a dummy for interaction between parental status and the female dummy is controlled. The standard errors in parentheses are robust standard errors with clustering at the individual level. ${ }^{* * *} \mathrm{p}<0.01,{ }^{* *} \mathrm{p}<0.05$, ${ }^{*} \mathrm{p}<0.1$. 
children (3 years or more). ${ }^{29}$ These findings suggest that, in addition to parenthood, other potential explanations such as theories of employer statistical discrimination and gender differences in bargaining skills cannot be ruled out. The latter explanation appears to be consistent with empirical evidences in Sweden. For instance, SäveSöderbergh (2007), based on recent college graduates in Sweden shows that women tend to submit a lower wage bid and are offered lower wages than men, despite having similar individual and job attributes. Another Swedish study based on a laboratory experiment of 204 students also finds evidence consistent with the wage bargaining hypothesis, where males are more likely than women to initiate wage bargaining (Eriksson and Sandberg, 2012).

\section{Conclusion}

This paper investigated the role of job and occupational mobility in explaining the gender gap in early career wage growth among university graduates in Sweden. Using rich Swedish register data for the period from 1996-2012, we first showed that a sizable part of the male-female gap in wages arises during the first ten years in the labor market. We find that the gender wage gap increases by approximately 12 percentage points within 10 years after labor market entry, which is equivalent to a $1.2 \%$ gender gap in the annual wage growth.

The analyses showed that although job and upward occupational mobility significantly contributes to the early career wage growth of both males and females, the sizes of the wage growth effect of both types of mobility are significantly lower for females than males. After accounting for human capital, demographic and job characteristics, the wage growth associated with job and upward occupational mobility for women is half and one-quarter lower than that of men, respectively. These gender differences in returns to job and upward occupational mobility together explain about $16 \%$ of the gender wage gap that is created after 10 years in the labor market. The above result is robust after accounting for unobserved individual-specific heterogeneity and alternative

\footnotetext{
${ }^{29}$ In Appendix Table A6 we report the female penalty in returns to voluntary job mobility for a childless group who do not expect to have a child for at least the next three years. Although women's incentive/pressure to change to family-friendly jobs at the cost of wage rewards is expected to be low for these childless groups, we still find a significant female penalty in returns to voluntary job mobility that is comparable with the female penalty on the years of childbirth and childcare. The finding supports the idea that other explanations such is gender differences in wage bargaining skills could be a possible explanation.
} 
model specifications. Considering the interrelationship between job and upward occupational mobility, we investigated whether the result on gender differential returns to upward occupational mobility is solely driven by firm change. However, the evidence showed that there is a substantial gender difference in the return to upward occupational mobility, both within and between firms. Further classification of job mobility into voluntary and involuntary firm change reveals that the women's penalty is mainly driven by voluntary firm changes.

We investigated to what extent the women's penalty in returns to voluntary job and upward occupational mobility is explained by parental status. The analysis showed that the gender gap in returns to upward occupational mobility is largely linked with the timing of childbirth and childcare. Regarding job mobility, although a significant female penalty is found among the childless as well as parents, anticipation of parenthood within the next year is found to exacerbate the female penalty in returns to job mobility.

This study highlighted the importance of job and upward occupational mobility to the creation of the gender gap in early career wage growth. The analysis also showed that the female penalty in returns to upward occupational mobility is mainly driven by parents with very young children. To the extent that Swedish women take a longer parental leave than men, a typical explanation for the motherhood wage growth penalty is that human capital depreciation or skill atrophy could occur during the period outside work. Although such an argument gained empirical support in the US and other countries, studies for Sweden and Denmark found no empirical support in this regard (Albrecht et al., 1999, Gupta and Smith, 2002). A plausible explanation is that women's greater responsibility for childbearing and childcare may undermine the work and effort put into the market work and thereby the labor market outcome (Becker, 1985). For example, according the 2010 time use survey for Sweden, women on average spend about 24 hours per week on domestic work, which is higher that men's 18 hours per week. Consequently, women who receive promotions to higher occupational positions while having a young child may find it difficult to cope with the new job demands (in terms of working long hours, traveling or exerting more effort).

In contrast to upward occupational mobility, the female penalty in returns to job mobility does not change with parental status. It should, however, be noted that the expectation of future childbirth may influence job mobility decisions before childbirth, which 
in turn affects the job mobility outcome among the childless. We have observed such an indication from the analysis, where the female job mobility penalty is found to be one of the highest among graduates who will have children within the next year. However, explanations based on parenthood in relation to compensating wage differential should be one part of the story if one also considers the significant female penalty among the childless who do not expect to have children within one year and those who had a child 3 or more years ago. Other potential explanations based on theories of employer statistical discrimination and gender differences in wage bargaining skills cannot be ruled out. In particular, explanations based on gender difference in wage bargaining skills appears to be the most plausible explanation, which has received empirical support by previous Swedish studies such as Säve-Söderbergh, 2007 and Eriksson and Sandberg, 2012. Further studies examining the relative importance of explanations based on gender differences in wage bargaining skills and family considerations when changing jobs could be informative to set the agenda for policy priorities. 


\section{References}

Addison, J. T., Ozturk, O. D., Wang, S. (2014) “The Role of gender in Promotion and Pay Over a Career” Journal of Human Capital, 8(3), 280-317

Albrecht, J., Björklund A., Vroman, S. (2003) “Is there a glass ceiling in Sweden?”, Journal of Labor Economics, 21(1),145-177.

Albrecht, J.W., Edin, P., Sundström, M. and Vroman, S. B., (1999)”Career Interruptions and Subsequent Earnings: A Reexamination Using Swedish Data” The Journal of Human Resources, 34(2), 294-311

Altonji, J. G., Blank, R. M. (1999). "Race and gender in the labor market", in Orley Ashenfelter and David Card, (eds.), Handbook of Labor Economics. Volume 3C: 3143-259, Amsterdam: North-Holland.

Angelov, N., Johansson P., and Lindahl E. (2016) "Parenthood and the Gender Gap in Pay” Journal of Labor Economics, 34(3), 545-579

Bartel, A. P., Borjas, G. J. (1981) "Wage Growth and Job Turnover: An Empirical Analysis” in Sherwin Rosen (ed.) Studies in Labor Markets, University of Chicago press.

Becker, G. (1985) "Human Capital, Effort, and the Sexual Division of Labor," Journal of Labor Economics, University of Chicago Press, 3(1), 33-58.

Belley, P., Havet N., Lacroix G. (2015) "Wage Growth and Job Mobility in the Early Career: Testing Statistical Discrimination Model of Gender Wage Gap” in Solomon W. Polachek, K, Konstantinos Tatsiramos, Klaus F. Zimmermann (ed) Gender in the Labor Market (Research in Labor Economics, Volume 42) Emerald Group Publishing Limited, 231-260

Bertrand, M., Goldin C., Katz L. F. (2010) ”Dynamics of the Gender Gap for Young Professional in the Financial and Corporate Sectors” American Economic Journal: Applied Economics 2(3), 228-255

Bertrand, M., Hallock K. F. (2001) ”The Gender Gap in Top Corporate Jobs” Industrial and Labor Relations Review, 55, 3-21 
Bertrand, M. (2011) “New Perspectives on Gender”. In Orley Ashenfelter and David card (eds.) Handbook of Labor Economics, vol 4b, Amsterdam: Elsevier, 1543-1590

Blau, F. D., Kahn L. M. (2006) ”The U.S. Gender Pay Gap in the 1990s: Slowing Convergence” Industrial and Labour Relations Review, 60(1), 45-66

Bowles, H.R. (2012) "Psychological Perspectives on Gender in Negotiation" in Michelle k. Ryan \& Nyla R. Branscombe (eds.) The SAGE Handbook of Gender and Psychology, SAGE Publication Ltd, London.

Carlsson, M., Reshid, A. A., Rooth, D. (2015) "Explaining the Gender Wage Gap Among Recent College Graduates - Pre-labor Market Factor or Employer Discrimination” Center for Labor Market Discrimination Studies, 2015:07, Linnaeus University

Del Bono, E., Vuri, D. (2011) "Job mobility and the gender wage gap in Italy” Labour Economics, 18, 130-142

Evertsson M., England P., Mooi-Reci I., Hermsen J., de Bruijn J., Cotter, D. (2009), “Is Gender Inequality Greater at Lower or Higher Educational Levels? Common Patterns in the Netherlands, Sweden, and the United States”, Social Politics, 16, 210241.

Evertsson, M. and Duvander., A. (2010) "Parental Leave- Possibility or Trap? Does Family Leave Length Effect Swedish Women’s labor Market Opportunity?” European Sociological Review, 27(4): 435-450

Eriksson, K. H., Sandberg, A. (2012) "Gender Differences in Initiation of Negotiation: Does the Gender of the Negotiation Counterpart Matter?” Negotiation Journal, 407428. Doi: 10.1111/j.1571-9979.2012.00349.x

Fitzenberger, B., Kunze, A. (2005) "Vocational Training and Gender: Wages and Occupational Mobility among Young Workers” Oxford Review of Economics Policy, 21(3), 392-415.

Fryer, R. G. (2007) "Belief flipping in a dynamic model of statistical discrimination” Journal of Public Economics, 91(2-6):1151-1166 
Fuller, S. (2008) "Job Mobility and Wage Trajectories for Men and Women in the United States” American Sociological Review, 73, 158-183

Ganzeboom, H. B. G., Treiman, D. J. (1996) “Internationally Comparable Measure of Occupational Status for the 1988 International Standard Classification of Occupations” Social Science Research, 25(0010), 201-239

Goldin, C. (2014) “A Grand Gender Convergence: Its Last Chapter” The American Economic Review, 104(4), 1091-1119.

Gupta, N.D. and Smith, N. (2002) “Children and Career Interruptions: The Family Gap in Denmark” Economica, New Series, 69(276), 609-629

Hotz, V.J., Johansson, P. \& Karimi, A. (2017) "Parenthood, Family Friendly Firms, and the Gender Gaps in Work Careers" Unpublished manuscript, Retrieved from http://economics.uwo.ca/about_us/Workshops/applied_docs_2016_2017/hotz_mar8. $p d f$.

Jacobs, J. A. (1992) “Women’s Entry into Management: Trends in Earnings, Authority, and Values Among Salaried Managers” Administrative Science Quarterly, 37(2), 282-301

Joshi, H., Paci, P., Waldfogel, J. (1999) “The wages of motherhood: better or worse?” Cambridge Journal of Economics, 23, 543-564

Jovanovic, B. (1979) “Job Matching and the Theory of Turnover” The Journal of Political Economy, 87(5), 972-990

Johnson, W. R. (1978) “A Theory of Job Shopping” The Quarterly Journal of Economics, 92(2), 261-278

Keith, K. and McWilliams, A. (1997) “Job Mobility and Gender-Based Wage Growth Differentials” Economic Inquiry, vol. XXXV, 320-333

Lazear and Sherin Rosen (1990) "Male-Female Wage Differentials in Job Ladders" Journal of Labor Economics, 8(1), 106-123

Le Grand, C. (1991) "Explaining the Male-Female Wage Gap: Job Segregation and Solidarity Wage Bargaining”, Acta Sociologica, 34, 261-278. 
Le Grand, C., Tåhlin, M. (2002) “Job Mobility and Earnings Growth” European Sociological Review, 18(4), 381-400

Looze, J. (2014) “Young Women’s Job Mobility: The Influence of Motherhood Status and Education” Journal of Marriage and Family 76: 693-709

Loprest, P. J., (1992) “Gender Differences in Wage Growth and Job Mobility”, The American Economic Review, 82(2), 526-532

Korenman , S., Neumark, D. (1992) “Marriage Motherhood and wages”, Journal of Human Resources, 27(2), 233-255

Magnusson, C. (2010) "Why Is There a Gender Wage Gap According to Occupational Prestige? An Analysis of the Gender Wage Gap By Occupational Prestige and Family Obligations in Sweden” Acta Sociologica, 53(2), 99-116

Manning, A., Swaffield, J. (2008) “The gender gap in early-career wage growth”, The Economic Journal, 118: 983-1024.

McCall, B. P. (1990) “Occupational Matching: A Test of Sorts” Journal of Political Economy, 98(1), 45-69.

Mincer, J., Polachek, S. (1974) "Family Investments in Human Capital: Earnings of Women” Journal of Political Economy,82,76-108

Mincer, J. (1986) "Wage Changes in Job Changes" Research in Labor Economics, 8A, 171-197.

Napari, S., (2009) “Gender difference in early-career wage growth” Labor Economics, $16,140-148$

OECD (2016) Organization for Economic Co-operation and Development, the data on gender gap can be found at http://www.oecd.org/gender/data/genderwagegap.htm

Phelps, E. (1972) "The Statistical Theory of Racism and Sexism", American Economic Review: 62(4), 659-61

Säve-Söderbergh, J. (2007) “Are Women Asking for Low Wages? Gender Differences in Wage Bargaining Strategies and Ensuing Bargaining Success” Working Paper 7/2007, Swedish Institute for Social Research, Stockholm University 
Treiman, D. J. (1976) “A Standard Occupational Prestige Scale for Use with Historical Data” The Journal of Interdisciplinary History, 7(2), 283-304

Wood, R. G., Corcoran M. E., Courant P. N. (1993) "Pay Differences among the Highly Paid: The Male-Female Earnings Gap in Lawyers’ Salaries” Journal of Labor Economics, 11(3), 417-441 


\section{Appendix}

Table A1. Summary statistics for male and female graduates

\begin{tabular}{|c|c|c|c|}
\hline \multirow[b]{2}{*}{ Variables } & \multicolumn{2}{|c|}{ Mean } & \multirow[b]{2}{*}{ Gender Gap } \\
\hline & Female & Male & \\
\hline Wage Growth & 0.042 & 0.050 & -0.008 \\
\hline Annualized wage growth ${ }^{a}$ & 0.037 & 0.047 & -0.010 \\
\hline Occupational mobility $(1 / 0)$ & 0.062 & 0.073 & -0.011 \\
\hline Job mobility (1/0) & 0.126 & 0.130 & -0.004 \\
\hline Voluntary job mobility & 0.114 & 0.108 & 0.006 \\
\hline Involuntary job mobility & 0.012 & 0.022 & -0.010 \\
\hline Potential experience & 5.667 & 5.741 & -0.074 \\
\hline Tenure & 4.585 & 4.358 & 0.227 \\
\hline \# of gaps between consecutive observation & 0.170 & 0.073 & 0.097 \\
\hline \# of gaps due to unemployment & 0.004 & 0.001 & 0.003 \\
\hline Age & 32.770 & 33.260 & -0.490 \\
\hline Married (1/0) & 0.399 & 0.371 & 0.028 \\
\hline Parent (1/0) & 0.551 & 0.498 & 0.053 \\
\hline Childless (at $t$ and $t+1$ ) & 0.375 & 0.445 & -0.070 \\
\hline Will have first child next year & 0.069 & 0.055 & 0.014 \\
\hline Year of $1^{\text {st }}$ birth & 0.026 & 0.060 & -0.034 \\
\hline Had a child & 0.290 & 0.290 & 0.000 \\
\hline 3 or more years after last birth & 0.240 & 0.150 & 0.090 \\
\hline Years of Education (2-5) & 3.229 & 3.260 & -0.032 \\
\hline \multicolumn{4}{|l|}{ Field of Education } \\
\hline Teachers training & 0.309 & 0.160 & 0.149 \\
\hline Humanities and Arts & 0.035 & 0.034 & 0.001 \\
\hline Social Science & 0.176 & 0.192 & -0.016 \\
\hline Natural Science & 0.041 & 0.073 & -0.031 \\
\hline Technology & 0.079 & 0.373 & -0.294 \\
\hline Agriculture & 0.005 & 0.010 & -0.005 \\
\hline Health & 0.333 & 0.102 & 0.232 \\
\hline Service & 0.022 & 0.056 & -0.034 \\
\hline unspecified & 0.000 & 0.000 & 0.000 \\
\hline \multicolumn{4}{|l|}{ Sector of Employment } \\
\hline private sector- with hourly wage & 0.010 & 0.034 & -0.023 \\
\hline private sector- with monthly salary & 0.277 & 0.555 & -0.278 \\
\hline Public sector-Municipality & 0.426 & 0.222 & 0.204 \\
\hline Public sector- regional level & 0.098 & 0.136 & -0.038 \\
\hline Public sector-State & 0.189 & 0.053 & 0.137 \\
\hline
\end{tabular}




\begin{tabular}{|c|c|c|c|}
\hline \multirow[b]{2}{*}{ Variables } & \multicolumn{2}{|c|}{ Mean } & \multirow[b]{2}{*}{ Gender Gap } \\
\hline & Female & Male & \\
\hline \multicolumn{4}{|l|}{ Occupation } \\
\hline Legislators, senior officials and manager & 0.032 & 0.069 & -0.038 \\
\hline Professionals & 0.480 & 0.507 & -0.027 \\
\hline Technicians and associate professionals & 0.421 & 0.340 & 0.081 \\
\hline Clerks & 0.029 & 0.023 & 0.006 \\
\hline Service workers and shop sales workers & 0.030 & 0.027 & 0.004 \\
\hline Skilled agricultural and fishery workers & 0.001 & 0.001 & 0.000 \\
\hline Craft and related trades workers & 0.001 & 0.010 & -0.009 \\
\hline Plant and machine operators and assemblers & 0.003 & 0.019 & -0.016 \\
\hline Elementary occupations & 0.003 & 0.004 & -0.001 \\
\hline \multicolumn{4}{|l|}{ Firm Size } \\
\hline less than 10 & 0.001 & 0.002 & -0.001 \\
\hline $10-49$ & 0.013 & 0.020 & -0.007 \\
\hline $49-249$ & 0.047 & 0.085 & -0.038 \\
\hline $250-499$ & 0.040 & 0.072 & -0.032 \\
\hline $500-999$ & 0.072 & 0.122 & -0.050 \\
\hline greater or equal to 1000 & 0.826 & 0.698 & 0.128 \\
\hline \multicolumn{4}{|l|}{ Industry } \\
\hline Agriculture and Fishing & 0.006 & 0.010 & -0.004 \\
\hline Mining & 0.001 & 0.002 & -0.001 \\
\hline Manufacturing & 0.074 & 0.229 & -0.155 \\
\hline Electricity and Gas & 0.004 & 0.014 & -0.010 \\
\hline Construction & 0.006 & 0.028 & -0.021 \\
\hline Sales & 0.002 & 0.003 & -0.001 \\
\hline Hotel and Restaurant & 0.002 & 0.002 & 0.000 \\
\hline Transport and Communication & 0.044 & 0.065 & -0.021 \\
\hline Finance & 0.031 & 0.050 & -0.019 \\
\hline Real estate Development & 0.072 & 0.161 & -0.089 \\
\hline Public Administration & 0.065 & 0.102 & -0.037 \\
\hline Education & 0.162 & 0.094 & 0.068 \\
\hline Health and Social Works & 0.507 & 0.214 & 0.293 \\
\hline Other community activities & 0.025 & 0.028 & -0.003 \\
\hline
\end{tabular}

Note: a) The annual wage growth is defined as $\left(\frac{w_{t}-w_{t-s}}{s}\right)$. 
Table A2. Gender wage gap with controls for pre-market factors

\begin{tabular}{ccc}
\hline Experience & Female-Male Gap & Standard error \\
& $\mathbf{( 1 )}$ & $\mathbf{( 2 )}$ \\
\hline 1 & $-0.042^{* * *}$ & 0.001 \\
3 & $-0.045^{* * *}$ & 0.001 \\
4 & $-0.051^{* * *}$ & 0.002 \\
5 & $-0.057^{* * *}$ & 0.002 \\
6 & $-0.062^{* * *}$ & 0.002 \\
7 & $-0.074^{* * *}$ & 0.002 \\
8 & $-0.081^{* * *}$ & 0.002 \\
9 & $-0.087^{* * *}$ & 0.002 \\
10 & $-0.093^{* * *}$ & 0.002 \\
\hline
\end{tabular}

Note: The dependent variable is the log real monthly wage. Each row in the above table represents a separate OLS estimate of the gender wage gap after controlling for pre-labor market factors (level and field of education, and graduate cohort*year fixed effect). 
Table A3. Gender gap in returns to job and occupational mobility. Robustness check with alternative model specification for number of gaps between observations

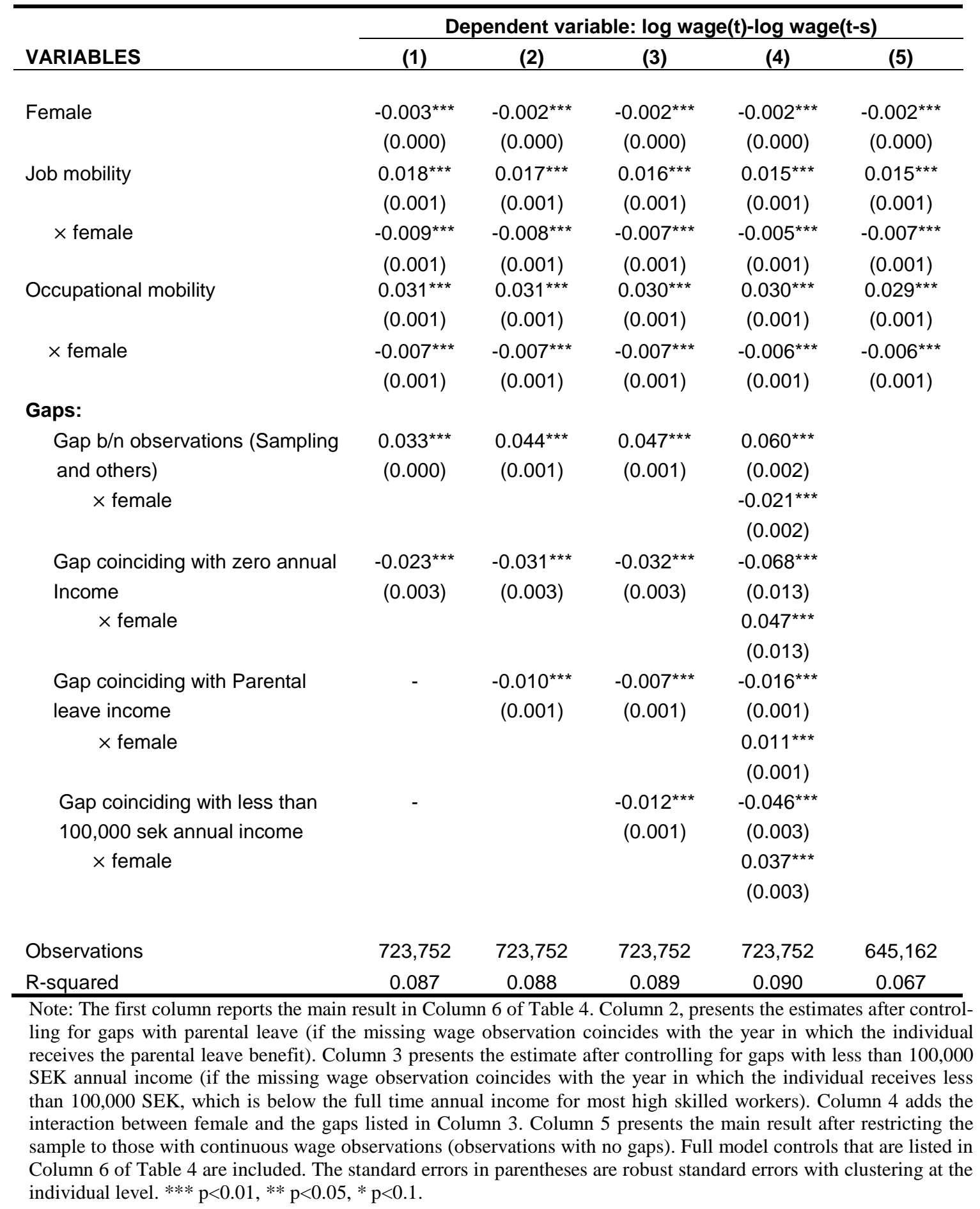


Table A4. Gender gap in returns to job and occupational mobility by parental status. Robustness check with alternative model specification for number of gaps between observations

\begin{tabular}{|c|c|c|c|c|c|}
\hline \multirow[b]{2}{*}{ VARIABLES } & \multicolumn{5}{|c|}{ Dependent variable: log wage(t)-log wage(t-s) } \\
\hline & (1) & $(2)$ & (3) & (4) & $(5)$ \\
\hline \multicolumn{6}{|l|}{ Occupational mobility } \\
\hline childless & $\begin{array}{c}0.029 * \star * \\
(0.001)\end{array}$ & $\begin{array}{c}0.028 * \star \star \\
(0.001)\end{array}$ & $\begin{array}{c}0.028 * * * \\
(0.001)\end{array}$ & $\begin{array}{c}0.027^{\star \star \star} \\
(0.001)\end{array}$ & $\begin{array}{c}0.025^{\star \star \star} \\
(0.001)\end{array}$ \\
\hline childless $\times$ female & $\begin{array}{c}-0.004^{\star *} \\
(0.002)\end{array}$ & $\begin{array}{c}-0.004^{\star \star} \\
(0.002)\end{array}$ & $\begin{array}{c}-0.004^{\star \star} \\
(0.002)\end{array}$ & $\begin{array}{l}-0.003 \\
(0.002)\end{array}$ & $\begin{array}{l}-0.003^{*} \\
(0.002)\end{array}$ \\
\hline parent & $\begin{array}{c}0.034^{\star \star *} \\
(0.002)\end{array}$ & $\begin{array}{c}0.034^{\star \star \star} \\
(0.002)\end{array}$ & $\begin{array}{c}0.034^{\star * *} \\
(0.002)\end{array}$ & $\begin{array}{c}0.033^{\star \star *} \\
(0.002)\end{array}$ & $\begin{array}{c}0.033^{\star * *} \\
(0.002)\end{array}$ \\
\hline Parent $\times$ female & $\begin{array}{c}-0.011^{\star * *} \\
(0.002)\end{array}$ & $\begin{array}{c}-0.011^{\star \star *} \\
(0.002)\end{array}$ & $\begin{array}{c}-0.010^{\star \star *} \\
(0.002)\end{array}$ & $\begin{array}{c}-0.010^{\star \star \star} \\
(0.002)\end{array}$ & $\begin{array}{c}-0.008^{\star \star *} \\
(0.002)\end{array}$ \\
\hline \multicolumn{6}{|l|}{ Voluntary Job mobility } \\
\hline childless & $\begin{array}{c}0.020 * * * \\
(0.001)\end{array}$ & $\begin{array}{c}0.017^{\star \star *} \\
(0.001)\end{array}$ & $\begin{array}{c}0.017^{\star * *} \\
(0.001)\end{array}$ & $\begin{array}{c}0.015^{\star \star \star} \\
(0.001)\end{array}$ & $\begin{array}{c}0.015^{\star \star \star} \\
(0.001)\end{array}$ \\
\hline childless $\times$ female & $\begin{array}{c}-0.010 * * * \\
(0.001)\end{array}$ & $\begin{array}{c}-0.010^{\star \star *} \\
(0.001)\end{array}$ & $\begin{array}{c}-0.009 * * * \\
(0.001)\end{array}$ & $\begin{array}{c}-0.007^{\star \star *} \\
(0.001)\end{array}$ & $\begin{array}{c}-0.008^{\star \star *} \\
(0.001)\end{array}$ \\
\hline parent & $\begin{array}{c}0.018^{\star \star \star} \\
(0.001)\end{array}$ & $\begin{array}{c}0.018^{\star \star \star} \\
(0.001)\end{array}$ & $\begin{array}{c}0.017^{\star \star \star} \\
(0.001)\end{array}$ & $\begin{array}{c}0.016^{\star \star \star} \\
(0.001)\end{array}$ & $\begin{array}{c}0.017^{\star \star \star} \\
(0.001)\end{array}$ \\
\hline Parent $\times$ female & $\begin{array}{c}-0.009 * * * \\
(0.001)\end{array}$ & $\begin{array}{c}-0.008^{\star \star *} \\
(0.001)\end{array}$ & $\begin{array}{c}-0.006^{\star \star \star} \\
(0.001)\end{array}$ & $\begin{array}{c}-0.005^{\star \star \star} \\
(0.001)\end{array}$ & $\begin{array}{c}-0.007^{\star \star \star} \\
(0.002)\end{array}$ \\
\hline \multicolumn{6}{|l|}{ Gaps: } \\
\hline $\begin{array}{l}\text { Gap b/n observations (Sampling } \\
\text { and others) } \\
\quad \times \text { female }\end{array}$ & $\begin{array}{c}0.031^{\star \star \star} \\
(0.000)\end{array}$ & $\begin{array}{c}0.044^{\star * *} \\
(0.001)\end{array}$ & $\begin{array}{c}0.047^{\star \star \star} \\
(0.001)\end{array}$ & $\begin{array}{c}0.060^{\star \star \star} \\
(0.002) \\
-0.020^{\star \star \star} \\
(0.002)\end{array}$ & \\
\hline $\begin{array}{l}\text { Gap coinciding with zero annual } \\
\text { Income }\end{array}$ & $\begin{array}{c}-0.022^{\star * *} \\
(0.003)\end{array}$ & $\begin{array}{l}-0.032^{\star \star \star} \\
(0.003)\end{array}$ & $\begin{array}{l}-0.033^{\star \star \star} \\
(0.003)\end{array}$ & $\begin{array}{l}-0.068^{\star \star \star} \\
(0.013)\end{array}$ & \\
\hline$\times$ female & & & & $\begin{array}{l}0.046 * \star \star \\
(0.013)\end{array}$ & \\
\hline $\begin{array}{l}\text { Gap coinciding with Parental } \\
\text { leave income } \\
\quad \times \text { female }\end{array}$ & & $\begin{array}{l}-0.011^{\star * *} \\
(0.001)\end{array}$ & $\begin{array}{c}-0.008^{\star \star \star} \\
(0.001)\end{array}$ & $\begin{array}{c}-0.016^{\star \star \star} \\
(0.001) \\
0.010^{\star \star \star} \\
(0.001)\end{array}$ & \\
\hline $\begin{array}{l}\text { Gap coinciding with less than } \\
\text { 100,000 sek annual income } \\
\quad \times \text { female }\end{array}$ & & & $\begin{array}{l}-0.013^{\star \star *} \\
(0.001)\end{array}$ & $\begin{array}{c}-0.046^{\star \star \star} \\
(0.003) \\
0.037^{\star \star \star} \\
(0.003)\end{array}$ & \\
\hline Female & $\begin{array}{l}-0.002^{\star \star \star} \\
(0.000)\end{array}$ & $\begin{array}{l}-0.002^{\star * *} \\
(0.000)\end{array}$ & $\begin{array}{l}-0.003^{\star * *} \\
(0.000)\end{array}$ & $\begin{array}{l}-0.002^{\star \star \star} \\
(0.000)\end{array}$ & $\begin{array}{c}-0.002^{\star \star \star} \\
(0.000)\end{array}$ \\
\hline Observations & 723,752 & 723,752 & 723,752 & 723,752 & 645,162 \\
\hline R-squared & 0.087 & 0.088 & 0.089 & 0.090 & 0.067 \\
\hline
\end{tabular}

Note: The first column reports the main result in Column 1 of Table 8. Column 2 presents the estimates after controlling for gaps with parental leave (if the missing wage observation coincides with the year in which the individual receives the parental leave benefit). Column 3 presents the estimate after controlling for gaps with less than 100,000 SEK annual income (if the missing wage observation coincides with the year in which the individual receives less than 100,000 SEK, which is below the full time annual income for most high skilled workers). Column 4 adds the interaction between female and the gaps listed in Column 3. Column 5 presents the main result after restricting the sample to those with continuous wage observations (observations with no gaps). The full model controls that are listed in Column 6 of Table 4 are included. The standard errors in parentheses are robust standard errors with clustering at the individual level. ${ }^{* * *} \mathrm{p}<0.01,{ }^{* *} \mathrm{p}<0.05,{ }^{*} \mathrm{p}<0.1$. 
Table A5. Gender gap in returns to job and occupational mobility by years since birth. Robustness check with alternative model specification for number of gaps between observations

\begin{tabular}{|c|c|c|c|c|c|}
\hline \multirow[b]{2}{*}{ VARIABLES } & \multicolumn{5}{|c|}{ Dependent Variable: log wage(t)-log wage(t-s) } \\
\hline & (1) & (2) & (3) & (4) & (5) \\
\hline \multicolumn{6}{|l|}{ Occupational mobility } \\
\hline Childless (at $t$ and $t+1$ ) & $\begin{array}{c}0.028^{\star \star \star} \\
(0.002)\end{array}$ & $\begin{array}{c}0.028^{\star \star \star} \\
(0.002)\end{array}$ & $\begin{array}{l}0.027^{\star \star \star} \\
(0.002)\end{array}$ & $\begin{array}{c}0.027^{\star \star *} \\
(0.002)\end{array}$ & $\begin{array}{l}0.025^{\star \star \star} \\
(0.002)\end{array}$ \\
\hline$\times$ Female & $\begin{array}{l}-0.004^{\star \star} \\
(0.002)\end{array}$ & $\begin{array}{l}-0.004^{\star \star} \\
(0.002)\end{array}$ & $\begin{array}{c}-0.004^{\star \star} \\
(0.002)\end{array}$ & $\begin{array}{l}-0.003 \\
(0.002)\end{array}$ & $\begin{array}{l}-0.003 \\
(0.002)\end{array}$ \\
\hline Will have first child next year & $\begin{array}{c}0.026^{\star \star \star} \\
(0.004)\end{array}$ & $\begin{array}{c}0.026^{\star \star \star} \\
(0.004)\end{array}$ & $\begin{array}{c}0.026^{\star \star \star} \\
(0.004)\end{array}$ & $\begin{array}{c}0.025^{\star \star \star} \\
(0.004)\end{array}$ & $\begin{array}{c}0.022^{\star \star \star} \\
(0.004)\end{array}$ \\
\hline$\times$ Female & $\begin{array}{l}-0.001 \\
(0.005)\end{array}$ & $\begin{array}{l}-0.001 \\
(0.005)\end{array}$ & $\begin{array}{l}-0.001 \\
(0.005)\end{array}$ & $\begin{array}{c}0.001 \\
(0.005)\end{array}$ & $\begin{array}{l}-0.001 \\
(0.005)\end{array}$ \\
\hline Year of $1^{\text {st }}$ birth & $\begin{array}{c}0.033^{\star \star *} \\
(0.004)\end{array}$ & $\begin{array}{c}0.032^{\star \star *} \\
(0.004)\end{array}$ & $\begin{array}{c}0.032^{\star * *} \\
(0.004)\end{array}$ & $\begin{array}{c}0.031^{\star \star *} \\
(0.004)\end{array}$ & $\begin{array}{c}0.031^{\star * *} \\
(0.004)\end{array}$ \\
\hline$\times$ Female & $\begin{array}{c}-0.027^{\star \star \star} \\
(0.007)\end{array}$ & $\begin{array}{c}-0.027^{\star \star \star} \\
(0.007)\end{array}$ & $\begin{array}{c}-0.026 \text { *** } \\
(0.007)\end{array}$ & $\begin{array}{c}-0.025^{\star \star \star} \\
(0.007)\end{array}$ & $\begin{array}{c}-0.028^{\star \star \star} \\
(0.007)\end{array}$ \\
\hline Had a child $1-2$ years age & $\begin{array}{c}0.033^{\star \star \star} \\
(0.002)\end{array}$ & $\begin{array}{c}0.033^{\star \star \star} \\
(0.002)\end{array}$ & $\begin{array}{c}0.033^{\star \star \star} \\
(0.002)\end{array}$ & $\begin{array}{c}0.032^{\star \star \star} \\
(0.002)\end{array}$ & $\begin{array}{c}0.031^{\star \star \star} \\
(0.002)\end{array}$ \\
\hline$\times$ Female & $\begin{array}{c}-0.013^{\star \star \star} \\
(0.003)\end{array}$ & $\begin{array}{c}-0.013^{\star * *} \\
(0.003)\end{array}$ & $\begin{array}{c}-0.013^{\star \star \star} \\
(0.003)\end{array}$ & $\begin{array}{c}-0.012^{\star \star \star} \\
(0.003)\end{array}$ & $\begin{array}{c}-0.010 * \star \star \\
(0.003)\end{array}$ \\
\hline Had a child 3 or more years ago & $\begin{array}{c}0.037^{\star * *} \\
(0.003)\end{array}$ & $\begin{array}{c}0.036^{\star \star \star} \\
(0.003)\end{array}$ & $\begin{array}{c}0.036^{\star \star \star} \\
(0.003)\end{array}$ & $\begin{array}{c}0.036^{\star \star *} \\
(0.003)\end{array}$ & $\begin{array}{c}0.036^{\star \star *} \\
(0.003)\end{array}$ \\
\hline$\times$ Female & $\begin{array}{l}-0.006^{\star} \\
(0.003)\end{array}$ & $\begin{array}{l}-0.006^{\star} \\
(0.003)\end{array}$ & $\begin{array}{l}-0.006^{\star} \\
(0.003)\end{array}$ & $\begin{array}{l}-0.005 \\
(0.003)\end{array}$ & $\begin{array}{l}-0.007^{*} \\
(0.003)\end{array}$ \\
\hline \multicolumn{6}{|l|}{ Voluntary Job mobility } \\
\hline Childless (at $t$ and $t+1$ ) & $\begin{array}{c}0.022^{\star \star \star} \\
(0.001)\end{array}$ & $\begin{array}{c}0.020 * \star * \\
(0.001)\end{array}$ & $\begin{array}{c}0.020 \star \star \star \\
(0.001)\end{array}$ & $\begin{array}{c}0.018^{\star * *} \\
(0.001)\end{array}$ & $\begin{array}{c}0.019 * * * \\
(0.001)\end{array}$ \\
\hline$\times$ Female & $\begin{array}{c}-0.012^{\star \star \star} \\
(0.002)\end{array}$ & $\begin{array}{c}-0.012^{\star \star *} \\
(0.002)\end{array}$ & $\begin{array}{c}-0.011^{\star \star \star} \\
(0.002)\end{array}$ & $\begin{array}{c}-0.009 \star \star \star \\
(0.002)\end{array}$ & $\begin{array}{c}-0.011^{\star \star \star} \\
(0.002)\end{array}$ \\
\hline Will have first child next year & $\begin{array}{c}0.024^{\star \star \star} \\
(0.004)\end{array}$ & $\begin{array}{c}0.022^{\star \star \star} \\
(0.004)\end{array}$ & $\begin{array}{c}0.022^{\star \star \star} \\
(0.004)\end{array}$ & $\begin{array}{c}0.019 * \star \star \\
(0.004)\end{array}$ & $\begin{array}{c}0.019 \text { *** } \\
(0.004)\end{array}$ \\
\hline$\times$ Female & $\begin{array}{c}-0.019 * \star * \\
(0.004)\end{array}$ & $\begin{array}{c}-0.019 * \star * \\
(0.004)\end{array}$ & $\begin{array}{c}-0.018^{\star \star *} \\
(0.004)\end{array}$ & $\begin{array}{c}-0.015^{\star \star \star} \\
(0.004)\end{array}$ & $\begin{array}{c}-0.017^{\star \star *} \\
(0.004)\end{array}$ \\
\hline Year of $1^{\text {st }}$ birth & $\begin{array}{c}0.021^{\star \star \star} \\
(0.003)\end{array}$ & $\begin{array}{c}0.020^{\star \star \star} \\
(0.003)\end{array}$ & $\begin{array}{c}0.019 \text { *** } \\
(0.003)\end{array}$ & $\begin{array}{c}0.017^{\star \star \star} \\
(0.003)\end{array}$ & $\begin{array}{c}0.014^{\star \star \star} \\
(0.003)\end{array}$ \\
\hline$\times$ Female & $\begin{array}{l}-0.009 \\
(0.005)\end{array}$ & $\begin{array}{l}-0.008 \\
(0.005)\end{array}$ & $\begin{array}{l}-0.008 \\
(0.005)\end{array}$ & $\begin{array}{l}-0.004 \\
(0.005)\end{array}$ & $\begin{array}{l}-0.009 * \\
(0.005)\end{array}$ \\
\hline Had a child 1-2 years ago & $\begin{array}{c}0.018^{\star \star *} \\
(0.002)\end{array}$ & $\begin{array}{c}0.018^{\star \star \star} \\
(0.002)\end{array}$ & $\begin{array}{c}0.017^{\star \star \star} \\
(0.002)\end{array}$ & $\begin{array}{c}0.017^{\star \star \star} \\
(0.002)\end{array}$ & $\begin{array}{c}0.017^{\star * *} \\
(0.002)\end{array}$ \\
\hline$\times$ Female & $\begin{array}{c}-0.008^{\star \star \star} \\
(0.002)\end{array}$ & $\begin{array}{c}-0.007^{\star \star \star} \\
(0.002)\end{array}$ & $\begin{array}{c}-0.005^{\star \star} \\
(0.002)\end{array}$ & $\begin{array}{c}-0.005^{\star \star} \\
(0.002)\end{array}$ & $\begin{array}{c}-0.005^{\star \star} \\
(0.002)\end{array}$ \\
\hline Had a child 3 or more years ago & $\begin{array}{c}0.014^{\star \star \star} \\
(0.002)\end{array}$ & $\begin{array}{c}0.014^{\star \star \star} \\
(0.002)\end{array}$ & $\begin{array}{c}0.013^{\star \star \star} \\
(0.002)\end{array}$ & $\begin{array}{c}0.013^{\star \star \star} \\
(0.002)\end{array}$ & $\begin{array}{c}0.018^{\star \star \star} \\
(0.002)\end{array}$ \\
\hline$\times$ Female & $\begin{array}{c}-0.008^{\star * *} \\
(0.003)\end{array}$ & $\begin{array}{c}-0.008^{\star \star \star} \\
(0.003)\end{array}$ & $\begin{array}{l}-0.007^{\star *} \\
(0.003)\end{array}$ & $\begin{array}{c}-0.006^{\star *} \\
(0.003)\end{array}$ & $\begin{array}{c}-0.009 * * * \\
(0.003)\end{array}$ \\
\hline
\end{tabular}




\begin{tabular}{|c|c|c|c|c|c|}
\hline \multirow[b]{2}{*}{ VARIABLES } & \multicolumn{5}{|c|}{ Dependent Variable: log wage(t)-log wage(t-s) } \\
\hline & $(1)$ & $(2)$ & $(3)$ & $(4)$ & (5) \\
\hline \multicolumn{6}{|l|}{ Gaps (missing wage): } \\
\hline $\begin{array}{l}\text { Gap b/n observations (Sampling } \\
\text { and others) }\end{array}$ & $0.033^{\star \star \star}$ & $\begin{array}{l}0.044^{\star \star \star} \\
(0.001)\end{array}$ & $\begin{array}{l}0.047^{\star \star \star} \\
(0.001)\end{array}$ & $\begin{array}{l}0.060 \star \star \star \\
(0.002)\end{array}$ & \\
\hline$\times$ Female & & & & $\begin{array}{l}-0.020 * \star \star \\
(0.002)\end{array}$ & \\
\hline $\begin{array}{l}\text { Gap coinciding with zero annual } \\
\text { Income }\end{array}$ & $\begin{array}{l}-0.023^{\star \star \star} \\
(0.003)\end{array}$ & $\begin{array}{l}-0.032^{\star * *} \\
(0.003)\end{array}$ & $\begin{array}{l}-0.033^{\star * *} \\
(0.003)\end{array}$ & $\begin{array}{l}-0.069 * \star * \\
(0.013)\end{array}$ & \\
\hline$\times$ Female & & & & $\begin{array}{l}0.047^{\star * \star} \\
(0.013)\end{array}$ & \\
\hline $\begin{array}{l}\text { Gap coinciding with Parental } \\
\text { leave income }\end{array}$ & & $\begin{array}{l}-0.010 * \star \star \\
(0.001)\end{array}$ & $\begin{array}{l}-0.007^{\star \star \star} \\
(0.001)\end{array}$ & $\begin{array}{l}-0.015^{\star \star \star} \\
(0.001)\end{array}$ & \\
\hline$\times$ Female & & & & $\begin{array}{l}0.010 * * \star \\
(0.001)\end{array}$ & \\
\hline Gap coinciding with less than & & & $-0.013^{\star * \star}$ & $-0.046^{\star \star *}$ & \\
\hline 100,000 sek annual income & & & $(0.001)$ & $(0.003)$ & \\
\hline$\times$ Female & & & & $\begin{array}{l}0.037^{\star \star \star} \\
(0.003)\end{array}$ & \\
\hline Female & $-0.002^{\star \star \star}$ & $-0.002^{\star \star \star}$ & $-0.002^{\star \star *}$ & $-0.002^{\star \star *}$ & $-0.002^{\star \star \star}$ \\
\hline
\end{tabular}

Note: The first column reports the main result in Column 1 of Table 9. Column 2 presents the estimates after controlling for gaps with parental leave (if the missing wage observation coincides with the year in which the individual receives the parental leave benefit). Column 3 presents the estimate after controlling for gaps with less than 100,000 SEK annual income (if the missing wage observation coincides with the year in which the individual receives less than 100,000 SEK, which is below the full time annual income for most high skilled workers). Column 4 adds the interaction between female and the gaps listed in Column 3. Column 5 presents the main result after restricting the sample to those with continuous wage observations (observations with no gaps). The full model controls that are listed in Column 6 of Table 4 are included. The standard errors in parentheses are robust standard errors with clustering at the individual level. ${ }^{* * *} \mathrm{p}<0.01,{ }^{* *} \mathrm{p}<0.05,{ }^{*} \mathrm{p}<0.1$. 
Table A6. Gender gap in returns to job and occupational mobility by years since birth

\begin{tabular}{|c|c|c|}
\hline & OLS & FE \\
\hline Variables & $(1)$ & $(2)$ \\
\hline \multicolumn{3}{|l|}{ Occupational mobility } \\
\hline \multirow[t]{2}{*}{ Childless (at least for the next 3 years) } & $0.028^{\star \star \star}$ & $0.021^{\star \star \star}$ \\
\hline & $(0.002)$ & $(0.002)$ \\
\hline \multirow[t]{2}{*}{$\times$ Female } & -0.002 & -0.001 \\
\hline & $(0.002)$ & $(0.003)$ \\
\hline \multirow[t]{2}{*}{ Will have first child after 3 years } & $0.029 * \star \star$ & $0.024^{\star \star \star}$ \\
\hline & $(0.005)$ & $(0.005)$ \\
\hline \multirow[t]{2}{*}{$\times$ Female } & -0.008 & -0.005 \\
\hline & $(0.006)$ & $(0.007)$ \\
\hline \multirow[t]{2}{*}{ Will have first child after 2 years } & $0.030 * \star \star$ & $0.025^{\star \star \star}$ \\
\hline & $(0.004)$ & $(0.004)$ \\
\hline \multirow[t]{2}{*}{$\times$ Female } & $-0.012^{\star *}$ & -0.010 \\
\hline & $(0.006)$ & $(0.006)$ \\
\hline \multirow[t]{2}{*}{ Will have first child after 1 years } & $0.026^{\star \star \star}$ & $0.019 * \star *$ \\
\hline & $(0.004)$ & $(0.004)$ \\
\hline \multirow[t]{2}{*}{$\times$ Female } & -0.001 & 0.002 \\
\hline & $(0.005)$ & $(0.006)$ \\
\hline \multirow[t]{2}{*}{ Year of $1^{\text {st }}$ birth } & $0.033^{\star * *}$ & $0.027^{\star \star *}$ \\
\hline & $(0.004)$ & $(0.005)$ \\
\hline \multirow[t]{2}{*}{$\times$ Female } & $-0.027^{\star \star \star}$ & $-0.028^{\star \star \star}$ \\
\hline & $(0.007)$ & $(0.008)$ \\
\hline \multirow[t]{2}{*}{ Had a child $1-2$ years ago } & $0.033^{\star \star \star}$ & $0.027^{\star \star \star}$ \\
\hline & $(0.002)$ & $(0.002)$ \\
\hline \multirow[t]{2}{*}{$\times$ Female } & $-0.013^{\star \star \star}$ & $-0.010^{\star \star \star}$ \\
\hline & $(0.003)$ & $(0.003)$ \\
\hline \multirow[t]{2}{*}{ Had a child 3 or more years ago } & $0.037^{\star \star \star}$ & $0.033^{\star \star \star}$ \\
\hline & $(0.003)$ & $(0.003)$ \\
\hline \multirow[t]{2}{*}{$\times$ Female } & $-0.006^{*}$ & -0.005 \\
\hline & $(0.003)$ & $(0.004)$ \\
\hline \multicolumn{3}{|l|}{ Voluntary Job mobility } \\
\hline \multirow[t]{2}{*}{ Childless (at least for the next 3 years) } & $0.022^{\star \star \star}$ & $0.025^{\star \star \star}$ \\
\hline & $(0.002)$ & $(0.002)$ \\
\hline \multirow[t]{2}{*}{$\times$ Female } & $-0.012^{\star \star \star}$ & $-0.013^{\star * *}$ \\
\hline & $(0.002)$ & $(0.002)$ \\
\hline \multirow[t]{2}{*}{ Will have first child after 3 years } & $0.022^{\star \star \star}$ & $0.023^{\star \star \star}$ \\
\hline & $(0.004)$ & $(0.004)$ \\
\hline \multirow[t]{2}{*}{$\times$ Female } & $-0.013^{\star \star \star}$ & $-0.011^{\star *}$ \\
\hline & $(0.005)$ & $(0.005)$ \\
\hline \multirow[t]{2}{*}{ Will have first child after 2 years } & $0.019 * \star \star$ & $0.022^{\star \star \star}$ \\
\hline & $(0.004)$ & $(0.004)$ \\
\hline \multirow[t]{2}{*}{$\times$ Female } & $-0.012^{\star \star \star}$ & $-0.014^{\star \star \star}$ \\
\hline & $(0.004)$ & $(0.004)$ \\
\hline \multirow[t]{2}{*}{ Will have first child after 1 years } & $0.024^{\star \star \star}$ & $0.026 * \star \star$ \\
\hline & $(0.004)$ & $(0.004)$ \\
\hline \multirow[t]{2}{*}{$\times$ Female } & $-0.019 * \star \star *$ & $-0.020 \star \star \star *$ \\
\hline & $(0.004)$ & $(0.004)$ \\
\hline
\end{tabular}




\begin{tabular}{|c|c|c|}
\hline & OLS & FE \\
\hline Variables & $(1)$ & $(2)$ \\
\hline \multirow[t]{2}{*}{ Year of $1^{\text {st }}$ birth } & $0.021^{\star \star \star}$ & $0.025^{\star \star \star}$ \\
\hline & $(0.003)$ & $(0.004)$ \\
\hline \multirow[t]{2}{*}{$\times$ Female } & -0.009 & -0.008 \\
\hline & $(0.005)$ & $(0.006)$ \\
\hline \multirow[t]{2}{*}{ Had a child $1-2$ years ago } & $0.018^{* \star *}$ & $0.020^{\star * *}$ \\
\hline & $(0.002)$ & $(0.002)$ \\
\hline \multirow[t]{2}{*}{$\times$ Female } & $-0.008^{\star \star \star}$ & $-0.007^{\star \star *}$ \\
\hline & $(0.002)$ & $(0.002)$ \\
\hline \multirow[t]{2}{*}{ Had a child 3 or more years ago } & $0.014^{\star * *}$ & $0.016^{\star \star \star}$ \\
\hline & $(0.002)$ & $(0.003)$ \\
\hline \multirow[t]{2}{*}{$\times$ Female } & $-0.008^{\star \star \star}$ & $-0.005^{\star}$ \\
\hline & $(0.003)$ & $(0.003)$ \\
\hline \multirow[t]{2}{*}{ Female } & $-0.001^{\star \star \star}$ & \\
\hline & $(0.000)$ & \\
\hline \multirow[t]{2}{*}{ Constant } & -0.001 & -0.018 \\
\hline & $(0.022)$ & $(0.033)$ \\
\hline Observations & 723,752 & 723,752 \\
\hline R-squared & 0.088 & 0.067 \\
\hline Number of individuals & & 122,390 \\
\hline
\end{tabular}

Note: The full model controls that are listed in Column 6 of Table 4 are included. In addition, a dummy for interaction between parental status and the female dummy is controlled. The standard errors in parentheses are robust standard errors with clustering at the individual level. ${ }^{* * *} \mathrm{p}<0.01,{ }^{* *} \mathrm{p}<0.05,{ }^{*} \mathrm{p}<0.1$. 